\title{
Dating hydrothermal alteration and IOCG mineralization along a terrane-bounding fault zone: the Copper Lake deposit, Nova Scotia
}

\author{
Daniel J. Kontak ${ }^{1} \uparrow$, Douglas A. Archibald ${ }^{2}$, Robert A. Creaser ${ }^{3}$, and Larry M. Heaman ${ }^{3}$ \\ 1. Department of Earth Sciences, Laurentian University, Sudbury, Ontario, P3E 2C6, Canada \\ 2. Department of Geological Sciences, Queen's University, Kingston, Ontario, K7L 3N6, Canada \\ 3. Department of Earth and Atmospheric Sciences, University of Alberta, Edmonton, Alberta, T6G 2E3, Canada \\ †Corresponding author:<dkontak@laurentian.ca>
}

Date received 30 August 2008 g Date accepted 09 November 2008

\begin{abstract}
The Copper Lake area of mainland Nova Scotia is one of several vein-controlled mineralized (Cu-Au-Co) systems associated with widespread carbonate and iron-oxide alteration proximal to the east-trending Cobequid-Chedabucto Fault System. Although this mineralization has been known for decades, its metallogenic affinity remains poorly defined, and in recent years an IOCG (iron oxide-copper-gold) model has been suggested. In order to determine the age of mineralization and provide an important time constraint for developing a metallogenic model, direct dating of the mineralization and associated alteration was undertaken. At Copper Lake, mineralization occurs in a set of sulphide-carbonate fissure veins hosted by fine-grained metasedimentary rocks of the Middle Devonian Guysborough Group. Dating of the sulphide-alteration (pyrite) and phyllic-alteration (muscovite) stages of the ore system utilized the Re-Os and ${ }^{40} \mathrm{Ar} /{ }^{39} \mathrm{Ar}$ methods, respectively. The two different chronometers yield ages of about $320 \mathrm{Ma}$ and provide an absolute age for the mineralization. As part of this study additional geochronological data were obtained for detrital zircon (U-Pb age of $1634 \pm 11.2 \mathrm{Ma}$ ) from the host sedimentary rocks, as well as timing of thermal events at ca. $370-380 \mathrm{Ma}, 350 \mathrm{Ma}$ and $<300 \mathrm{Ma}$ based on whole rock ${ }^{40} \mathrm{Ar} /{ }^{39} \mathrm{Ar}$ and chemical Th-Pb dating of host rocks and monazite. The Th-Pb dating of monazite indicates that rare-earth element mobility accompanied mineralization. Collectively, the data indicate that the area experienced multiple thermal events, but hydrothermal activity related to mineralization is constrained to about $320 \mathrm{Ma}$ and is tentatively interpreted to relate to structural focusing of fluids that may have been driven by a mid-crustal level mafic heat source. The mineralizing event coincides with regional Alleghanian deformation in this part of the Appalachian orogen and thus reflects larger-scale tectonothermal processes.
\end{abstract}

\section{RÉSUMÉ}

Le secteur du lac Copper, dans la partie continentale de la Nouvelle-Écosse, constitue l'un de plusieurs systèmes minéralisés $(\mathrm{Cu}-\mathrm{Au}-\mathrm{Co})$ régis par des filons associés à une altération étendue en oxyde de fer et en carbonates proximale du système de failles orienté vers l'est de Cobequid-Chedabucto. Même si l'on connait cette minéralisation depuis des décennies, son affinité métallogénique demeure mal définie et des chercheurs ont avancé ces dernières années un modèle OFCO (oxyde de fer-cuivre-or). On a réalisé une datation directe de la minéralisation et de l'altération connexe pour déterminer l'âge de la minéralisation et établir une délimitation chronologique importante pour l'établissement d'un modèle métallogénique. Dans le secteur du lac Copper, la minéralisation est présente dans un ensemble de filons de fissures remplies de sulfures-carbonates à l'intérieur de roches métasédimentaires à grains fins du groupe du Dévonien moyen de Guysborough. Les méthodes Re-Os et ${ }^{40} \mathrm{Ar} /{ }^{39} \mathrm{Ar}$, respectivement, ont permis la datation des stades de la sulfuration (pyrite) et de l'altération phylliteuse (muscovite). Les deux différentes méthodes chronométriques ont fourni des âges d'environ 320 Ma et confèrent un âge absolu à la minéralisation. On a obtenu, dans le cadre de cette étude, des données géochronologiques supplémentaires de zircon détritique (datation U-Pb de $1634 \pm 11,2 \mathrm{Ma}$ ) des roches sédimentaires hôtes ainsi que le moment des événements thermiques, situés à environ $370-380 \mathrm{Ma}, 350 \mathrm{Ma}$ et $<300 \mathrm{Ma}$ d'après une datation de la roche totale ${ }^{40} \mathrm{Ar} /{ }^{39} \mathrm{Ar}$ et une datation chimique $\mathrm{Th}-\mathrm{Pb}$ des roches hôtes et de la monazite. La datation Th- $\mathrm{Pb}$ de la monazite révèle qu'une mobilité des métaux des terres rares a accompagné la minéralisation. Les données signalent collectivement que le secteur a connu plusieurs événements thermiques, mais que l'activité hydrothermale apparentée à la minéralisation est limitée à environ $320 \mathrm{Ma}$; on l'interprète provisoirement comme une activité liée à une concentration structurale des fluides qui pourrait avoir été provoquée par une source de chaleur mafique mi-crustale. L'épisode de minéralisation coïncide avec la déformation alléghanienne régionale dans cette partie de l'orogène des Appalaches et correspond en conséquence à des processus tectonothermaux à plus grande échelle.

\section{[Traduit par la redaction]}




\section{INTRODUCTION}

The metallogenic map of Nova Scotia (Chatterjee 1983) shows a high concentration of iron-oxide mineralization and associated base- and precious-metal enrichment proximal to the prominent, east-trending Cobequid-Chedabucto Fault System (CCFS, Fig. 1a) which separates the Avalon and Meguma terranes in this part of the Appalachian orogen. This metallogenic domain includes the past-producing iron mines of Londonderry (Wright 1975), as well as many smaller past producers (e.g., Copper Lake $\mathrm{Cu}-\mathrm{Au}$ ) and significant occurrences (e.g., Mt. Thom Cu-Co-Au north of Truro; Fig. 1a; Kontak 2006). Much of this mineralization is related to widespread carbonate- and iron -oxide alteration(i.e., specular hematite with magnetite absent) regardless of the age or nature of the host rock. The elemental association $(\mathrm{Cu}, \mathrm{Fe}, \mathrm{Au}, \mathrm{Co}$, $\mathrm{Ni}$ ), nature of the alteration (Fe-oxide and carbonate), and obvious spatial association with a major terrane-bounding fault system with a protracted history (Keppie 1982) suggest a possible metallogenic affinity with IOCG (iron oxide-copper-gold) mineralization (see Williams et al. 2005 for review). Consequently, the area has attracted considerable exploration interest in recent years (Downes and Setterfield 2004; O'Reilly 2005; Kontak 2006; Belperio 2007). Although a compilation of mineralization along the fault zone has been done (Ervine 1994) and some general studies completed at specific sites (Wright 1975; Kontak 2006; O'Reilly 2005), which indicate an epigenetic, structural control to the mineralization with associated alteration, no radiometric ages for the mineralization are available. Stratigraphic constraints suggest a post-Namurian age for similar alteration in the Cobequid Highlands (i.e., younger than about 325-315 Ma; Pe-Piper et al.2004; O’Reilly 2005; Kontak 2006). Given the importance of constraining the timing of this mineralization and its relationship to the geological evolution of the host rocks and surrounding area, a geochronological study was undertaken at one of the better mineralized sites, the past-producing Copper Lake deposit. This site has been studied in more detail than others (Kontak 2006) and, therefore, formed the basis for a comprehensive, multi-method (Re-Os, ${ }^{40} \mathrm{Ar} /{ }^{39} \mathrm{Ar}, \mathrm{U}-\mathrm{Pb}$, Th-Pb chemical dating) geochronologic study. In this paper, the results of this work are presented and discussed in the context of the possible origin of this IOCG-style mineralization. The results of ${ }^{40} \mathrm{Ar} /{ }^{39} \mathrm{Ar}$ dating obtained for other mineralized sites, such as Mt. Thom and surrounding area (Kontak et al. 2008), are currently being completed and will be presented elsewhere.

\section{GEOLOGICAL SETTING}

The Copper Lake area occurs north of the east-trending CCFS which separates the Meguma and Avalon terranes (Fig. 1). The area lies east of a thick sequence of OrdovicianDevonian volcanic and sedimentary rocks that drape part of the Precambrian Antigonish Highlands (Murphy et al. 1991) around Lochaber Lake, and Devonian-Carboniferous Horton and Windsor group rocks occur to the north and south (Tèniére 2002; Reynolds et al. 2004) (Fig. 1). The area of interest is underlain by mid-Devonian rocks of the Guysborough Group (Cormier et al. 1995; White and Barr 1998, 1999; Dunning et al. 2002) and is structurally bounded on all sides, which has led to the setting being interpreted to represent a positive flower structure related to dextral movement along the terrane-bounding CCFS to the south (Webster et al. 1998). Several major faults occur, which coincide with changes in rock type and structural trends (Kontak 2006), some of which are labeled in Figure 1. These faults include the north-trending Lochaber Lake and South River Lake faults and the northeast-trending Roman Valley and Glenroy faults. The Roman Valley Fault forms the structural break with Horton Group sedimentary rocks which underlie the Lochaber-Mulgrave area to the north, and has been discussed in detail by Tèniére (2002) and Reynolds et al. (2004). These structural discontinuities have been noted for some time and can be seen on earlier maps of the area (MacCormack 1966,1967). A cleavage-forming deformation event and associated low-grade metamorphism (lower greenschist facies) of the Horton Group rocks just north of the Roman Valley Fault are constrained to about 340 Ma based on ${ }^{40} \mathrm{Ar} /{ }^{39} \mathrm{Ar}$ plateau ages (Reynolds et al. 2004).

East of Copper Lake, where the historical copper mining occurred (Fig. 1), the area is underlain by rocks of the Middle Devonian Guysborough Group, as constrained by a U-Pb zircon age of 389 Ma reported by Cormier et al. (1995) for a rhyolite dome in this sequence, and a cross-cutting gabbroic pluton (Dunning et al. 2002). The stratigraphy is dominated by green- to grey-green siltstone and shale and grey to black laminated siltstone, silty shale, and shale. Both of these rock assemblages are present in drill core from the mineralized zone at Copper Lake (Black 1996; Kontak 2006). Based on core logging and assessment reports (Lacombe 1962; Black 1996), it appears that a package of mainly fine-grained, greenish sedimentary rocks is located on the north side of the area, whereas grey to black sedimentary rock units dominate in the south; locally the boundary between the two rock types is a zone of brittle deformation. The dark shale lithologies typically have thin $(<3-5 \mathrm{~mm})$ layers of sulphides, with pyrite dominant over pyrrhotite, that occur with quartz and carbonate extensional veins. Reference is made in drill records (e.g., Lacombe 1962) to the occurrence of andesite and rhyolite lithologies, which occur elsewhere in the Guysborough Group (Cormier et al. 1995), but these rocks were not observed in examination of the drill core from Copper Lake. In addition, there is reference to small plugs of intrusive rocks of mafic and felsic composition in the area based on the occurrence of erratics, but no detailed descriptions of the field relationships of such rocks were provided. Cameron (1951) referred to such a plug located west of Copper Lake as being of syenitic composition, but no igneous rocks are encountered in drill core or recent mapping in the area (e.g., White and Barr 1998). However, copper mineralization at College Grant, located west of Lochaber Lake, is associated with quartz-specularite veins in a Devonian dioritic intrusion (Murphy et al. 1991; Fig. 1). 

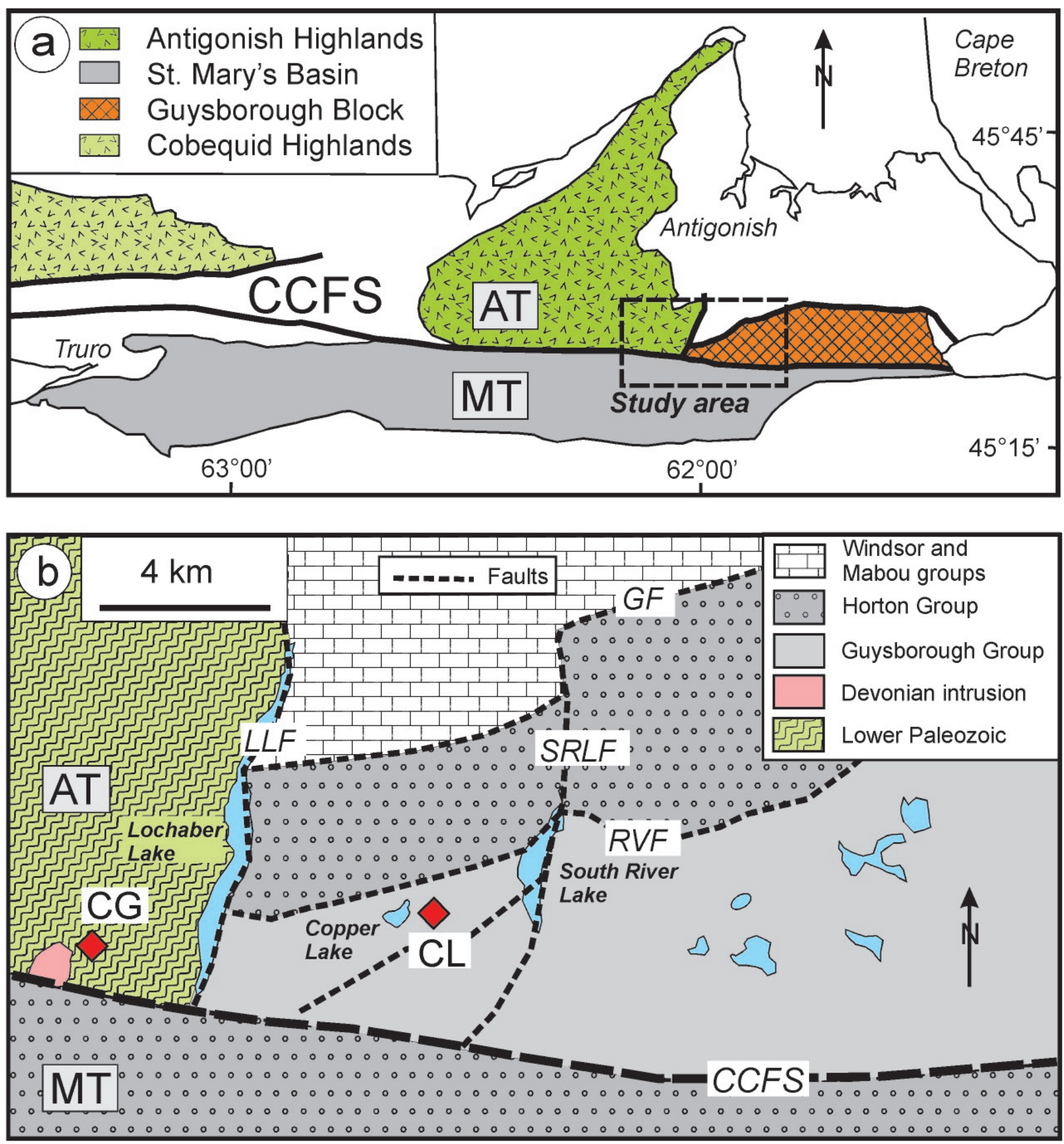

Fig. 1. (a) Location of the study area in the eastern part of mainland Nova Scotia showing the main geological features discussed in the paper. (b) Geological map of the Copper Lake area, northern mainland Nova Scotia. Map is modified after Keppie (2000) and Reynolds et al. (2004). Faults shown are as follows: Cobqeuid-Chedabucto Fault System (CCFS), South River Lake Fault (SRLF), Lochaber Lake Fault (LLF), Roman Valley Fault (RVF), and Glenroy Fault (GF). Location of the Copper Lake (CL) and College Grant (CG) mineralized sites are indicated. Note that the Meguma (MT) and Avalon (AT) terranes are also indicated in figures $a$ and $b$. 
The sequence of sedimentary rocks has been tightly folded into east- to northeast-trending folds, but the scale of these structures is not well constrained. A variably developed cleavage with an easterly to northeasterly trend and steep dip occurs regionally and in drill core small scale folding is commonly seen (Fig. 2a). The structural features observed in the study area are similar to those described in the younger Horton Group rocks to the north (Téniére 2002; Reynolds et al. 2004).
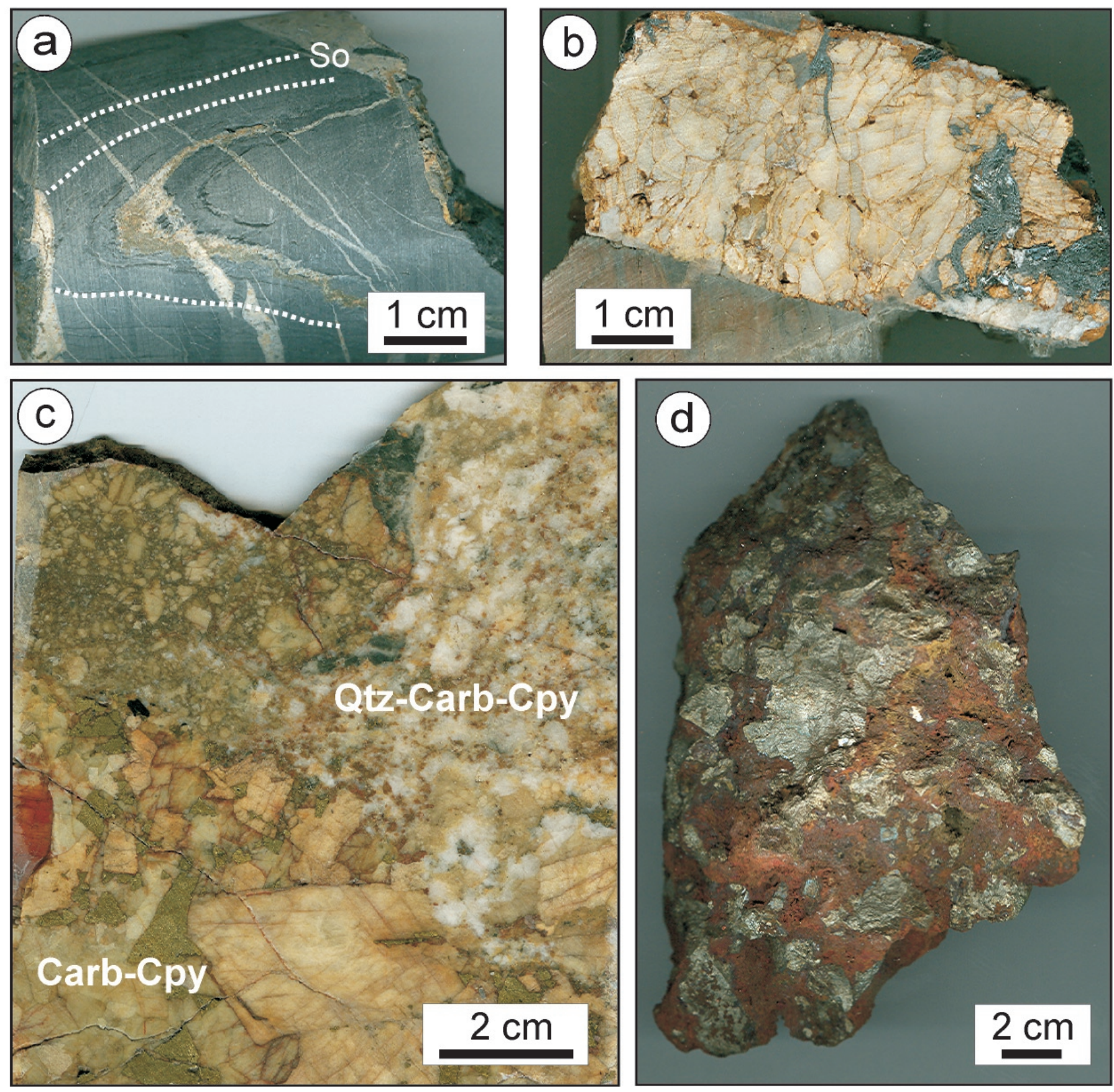

Fig. 2. Samples from Copper Lake $\mathrm{Cu}$-Au deposit. Note that the sample in (a) is from drill core and the others are from remnant piles of ore and waste material at the former mine site. (a) Core sample showing dark grey to black, laminated siltstone (note bedding $\left(\mathrm{S}_{\mathrm{o}}\right)$ is traced by dashed white line) with folded, bedding concordant quartz-Fe carbonate-pyrite vein cut by later quartz-carbonate extensional veins. (b) Slab of vein material showing Fe-carbonate with specular hematite (right part of sample) against altered (i.e., bleached) sedimentary wall rock on the left. (c) Cut slab of ore-grade, vein sample showing quartz-carbonate-chalcopyrite (Qtz-Carb-Cpy) and carbonate-chalcopyrite (Carb-Cpy) stages of mineralized material. Note the coarse, in part euhedral, grains of Fe carbonate mixed in with brecciated material. (d) Sample of massive vein pyrite with Fe-oxide (gossan) alteration. This sample was used for Re-Os isotopic analysis. 


\section{MINERALIZATION AND ALTERATION AT COPPER LAKE}

The mineralization at Copper Lake was confined to historical underground workings (Cameron 1951) and has been summarized by McMullin (1970). These reports indicate that the mineralized zones occur in east-trending, moderately to steeply dipping $\left(\leq 65^{\circ}\right)$ siderite-sulphide veins (Fig. 2b, c, d). Early workings of the veins produced ore with grades up to $10-12 \% \mathrm{Cu}$ with $0.24 \mathrm{oz}$. Au/t, $0.3 \mathrm{oz} . \mathrm{Ag} / \mathrm{t}$, and $0.1 \% \mathrm{Ni}$. Intersections of $>2 \% \mathrm{Cu}$ over about $3 \mathrm{~m}$ have been recorded. Analyses of sulphide concentrates from dump material have confirmed the elevated Au values (Kontak 2006). The veins are generally considered to fill subparallel fissures that relate to a series of faults in the area.

Based on examination of drill core and samples collected from dump piles, a detailed description of the mineralization was prepared by Kontak (2006), a summary of which follows: (1) there appears to be a continuum of veins which, importantly, cut cleaved wall rock, thereby suggesting a late origin with respect to penetrative deformation (Fig. 2a); (2) specular hematite is common in the siderite veins (Fig. 2b); (3) carbonate veins cutting sedimentary wall rock commonly have bleached alteration halos (Fig. 2b); (4) coarse pyrite and chalcopyrite are locally abundant in siderite veins (Fig. 2c); (5) breccia textures in massive vein samples (Fig. $2 c$ ) indicate that repeated opening, sealing, and deformation occurred during vein formation; and (6) the widespread occurrence of quartzhematite veins and areas of well developed extensional veins of quartz-carbonate-sulphide, particularly in the dark grey to black sedimentary rocks.

A detailed study of alteration based on petrographic study and imaging using the electron microprobe was presented in Kontak (2006) and is summarized below. The original mineral assemblage of the sedimentary rocks consists of variable mixtures of quartz, chlorite, white mica, and albite with, importantly, carbonate as a rare phase (Fig. 3a). In contrast, there is locally pervasive alteration of the host rocks (e.g., Fig. $3 \mathrm{~b})$ with development of quartz-carbonate-albite zones, either in similar proportions or variable mixtures, and a distinctive medium-grained, granoblastic texture (Fig. 3c, d,f). The alteration is peripheral to veins, but generally altered sections are vein free. In addition to the dominant minerals mentioned, variable amounts of muscovite, chlorite, apatite, rutile, clay (possibly kaolinite), and pyrite occur with trace amounts of chalcopyrite, monazite, zircon, xenotime, thorite, and unidentified rare-earth element phases (Fig. 3e, f; also see Kontak 2006). Apatite forms both within the altered wall rock and as part of the vein assemblage, thus linking the vein and alteration stages. Of particular note is the fact that the accessory phases, zircon, monazite, and xenotime, have sub- to euhedral habits and may occur as phases proximal to or within hydrothermal pyrite which indicates they are possibly of hydrothermal origin (Fig. 3e).

\section{SAMPLING AND ANALYTICAL PROCEDURES}

Samples for constraining the timing of mineralization at Copper Lake were collected from dump material adjacent to the former workings ( $6^{\circ}$ UTM $\left.5028375 \mathrm{~N}, 579915 \mathrm{E}\right)$ and diamond drill holes collared near the mineralized zone just east of Copper Lake (locations provided in Black 1996). Appropriate materials were sampled in order to undertake Re-Os and ${ }^{40} \mathrm{Ar} /$ ${ }^{39} \mathrm{Ar}$ dating, but subsequent petrographic work indicated the possibility for both TIMS U-Pb zircon dating and also in situ $\mathrm{Th}-\mathrm{Pb}$ chemical dating of monazite.

Six samples were collected for ${ }^{40} \mathrm{Ar} /{ }^{39} \mathrm{Ar}$ dating, four of these being fine-grained sedimentary rocks from drill holes (CPL-952 and 95-3; see descriptions in Black 1996) and two samples from the mine dumps. The two drill holes were collared peripheral to the main zone, but abundant veining and alteration occur throughout some sections, whereas the dump samples contained phyllic alteration of wall rock adjacent to carbonate-sulphide veins. In the latter case, a sample enriched in finegrained white mica was treated as a whole rock, whereas in the second sample a muscovite separate was prepared by handpicking from crushed material under a binocular microscope. The samples were analyzed at the Geochron Laboratories, Queen's University (Kingston, Ontario) using the following procedures. Samples and flux-monitors (standards) were wrapped in Al-foil and the resulting disks were stacked vertically into a $11.5 \mathrm{~cm}$ long and $2.0 \mathrm{~cm}$ diameter irradiation capsule. The capsule was

Fig. 3. (Following page) Photographs of core (b) and polished sections (back scattered electron (BSE) images) for fresh and altered rock samples from the Copper Lake area. In the BSE images the bright areas have higher average atomic number, e.g., quartz is darker than carbonate and pyrite is brighter than both of these. Abbreviations are quartz (Qtz), carbonate (Carb), albite (Alb), muscovite (Ms) and zircon (Zr). (a) Typical matrix of the fresh sedimentary rock showing isolated, anhedral grains of quartz (dark) and intergranular mica, clay minerals and feldspar (light grey). Note that there is only minor carbonate (bright areas). Compare this sample to altered samples in images shown in d, e, and f. (b) Intensely bleached sedimentary rock in area peripheral to abundant carbonate veins. The red material is finegrained hematite along bedding planes. (c) Secondary hydrothermal albite porphyroblasts (outlined in white dashed lines) overgrowing matrix phases in the sedimentary rock. (d) Altered sedimentary rock with quartz (med grey) - carbonate (bright phase) dominant and new pore space filled by muscovite and clay minerals (dark areas). (e) Altered sedimentary rock now composed of quartz-albite (dark areas) with later euhdral carbonate (grey), rare muscovite (Ms) and a zoned, $20 \mu \mathrm{m}$ size zircon euhedra (enlarged in the inset box). (f) Altered sedimentary rock with coarse quartz-carbonate and sub- to anhedral apatite (bright phases). 

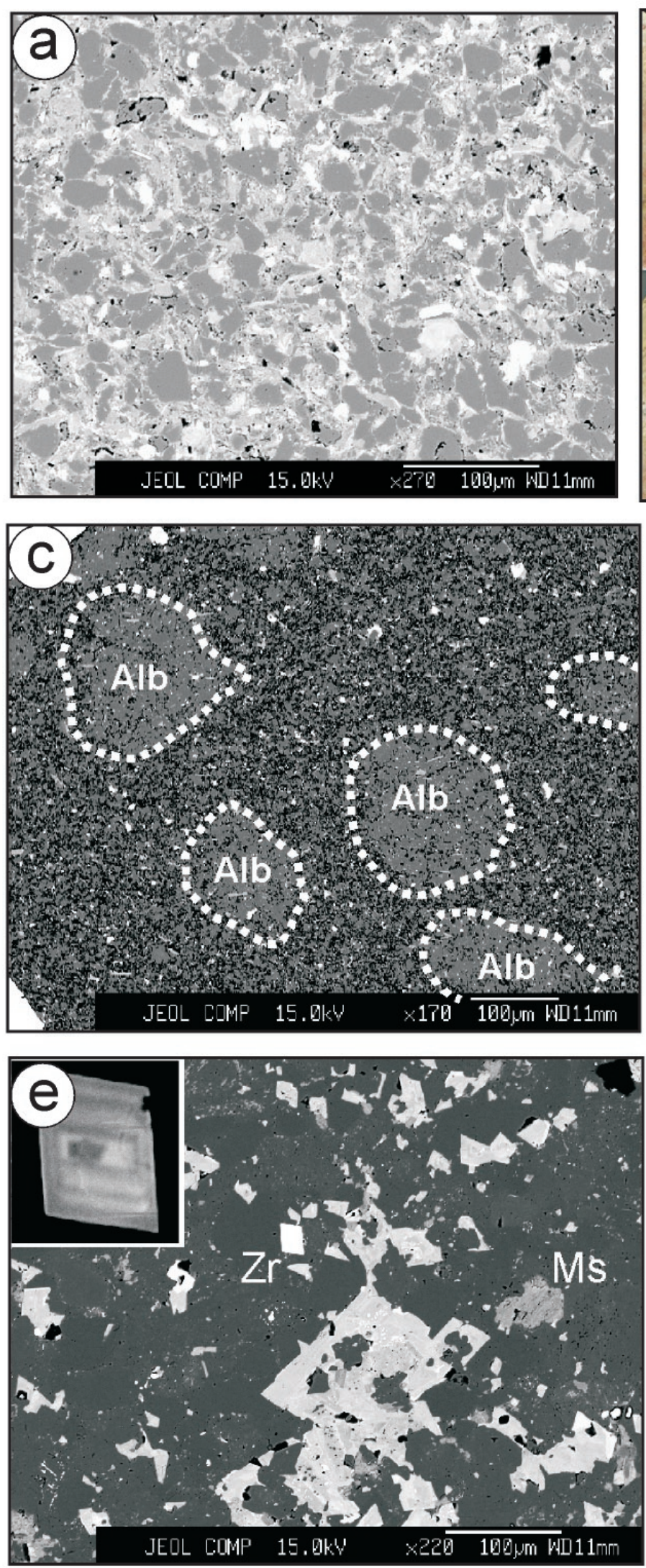
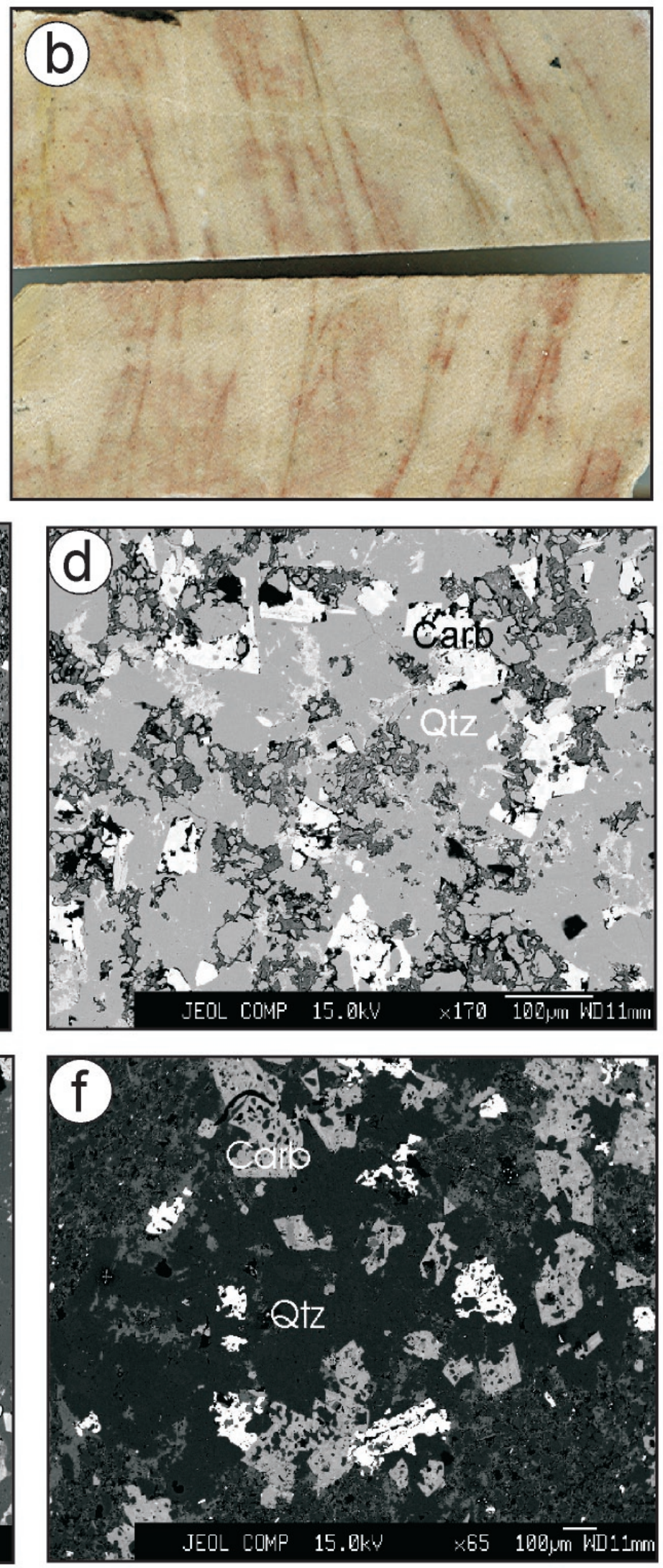
irradiated with fast neutrons in position $5 \mathrm{C}$ of the McMaster Nuclear Reactor (Hamilton, Ontario) for 27 hours (81 MWH with a neutron flux of ca. $4.3 \times 10^{16}$ neutrons $/ \mathrm{cm}^{2}$ ). Groups of flux monitors were located at ca. $1 \mathrm{~cm}$ intervals along the irradiation container and J-values for individual samples were determined by second-order polynomial interpolation between replicate analyses of splits for each monitor position in the capsule. No attempt was made to monitor horizontal flux gradients, as these are considered to be minor in the core of the reactor. For the samples analyzed in this study the J values ranged from $6.943 \times 10^{-3}$ to $6.789 \times 10^{-3}$. For total fusion of monitors using a laser, the samples are mounted in a copper sample-holder, beneath the view-port of a small, bakeable, stainless-steel chamber connected to an ultra-high vacuum purification system. An 8W Lexel 3500 continuous argonion laser was used for fusing flux monitors. For step-heating of samples in this study, the beam of a New Wave Research MIR10-30, $\mathrm{CO}_{2}$ laser was defocused to a $2300 \mu \mathrm{m}$ spot size. Heating periods were ca. 3 minutes at increasing power settings. The evolved gas, after purification using an SAES C50 getter (ca. 5 minutes), was admitted to an on-line, MAP 216 mass spectrometer, with a Baur-Signer source and an electron multiplier (set to a gain of 100 over the Faraday). Blanks, measured routinely, were subtracted from the subsequent sample gas-fractions. The extraction blanks were typically $<10 \times 10^{-13}$, $<0.5 \times 10^{-13},<0.5 \times 10^{-13}$, and $<0.5 \times 10^{-13} \mathrm{~cm}-3$ STP for masses $40,39,37$, and 36 , respectively.

Measured argon-isotope peak heights were extrapolated to zero-time, normalized to the ${ }^{40} \mathrm{Ar} /{ }^{36} \mathrm{Ar}$ atmospheric ratio (295.5) using measured values of atmospheric argon, and corrected for neutron-induced ${ }^{40} \mathrm{Ar}$ from potassium, ${ }^{39} \mathrm{Ar}$ and ${ }^{36} \mathrm{Ar}$ from calcium (using isotope production ratios of Escuder Viruete et al. 2006), and ${ }^{36} \mathrm{Ar}$ from chlorine (Roddick 1983). Dates and errors were calculated using formulae given by Dalrymple et al. (1981), and the constants recommended by Steiger and Jager (1977). Isotope correlation analysis used the formulae and error propagation of Hall (1981) and the regression of York (1969). Errors shown in the tables and on the age spectra and isotope correlation diagrams represent the analytical precision at $2 \sigma$, assuming that the error in the age of the flux monitor is zero. This approach is suitable for comparing within-spectrum variation and determining which steps form a plateau (McDougall and Harrison 1999). A conservative estimate of this error in the J-value is $0.5 \%$ and can be added for inter-sample comparison. The dates and J-values are referenced to $\mathrm{Hb} 3 \mathrm{Gr}$ hornblende at $1072 \mathrm{Ma}$ (Roddick 1983).

A sample of pyrite-rich, carbonate-sulphide rock (Fig. 2d) collected from the dump area surrounding the historical workings was collected for Re-Os dating. The rock was fragmented to provide fresh sulphide material, as most of the material recovered from the dump area has a gossanous outer layer. The newly exposed material is free of alteration, as confirmed from examination of ore petrology sections prepared from this sample. The sample was processed and analyzed at the Department of Earth and Atmospheric Sciences, University of Alberta (Edmonton, Alberta). The sulphide-bearing sample was first coarsely crushed and subsequently hand-picked to subdivide the sample into five high-purity pyrite separates. The $\mathrm{Re}$ and Os contents were determined by isotope dilution and negative thermal ionization mass spectrometry (ID-NTIMS) following procedures described by Morelli et al. (2004, 2005). Isochron ages were calculated by use of Isoplot/Ex V3.0 (Ludwig 2003) using fully propagated uncertainties in Re/Os and Os/Os together with the use of the error correlation function rho (see Morelli et al. 2005 for full details).

A section of drill core containing intensely bleached (i.e., pale grey white) siltstone with abundant disseminated pyrite was observed (thin section, imaging analysis) to contain an anomalous amount of sub- to euhedral zircon. This sample was processed for $\mathrm{U}-\mathrm{Pb}$ analysis of zircon at the Department of Earth and Atmospheric Sciences, University of Alberta (Edmonton, Alberta). The separation of zircon grains and their isotopic analysis follow procedures outlined in Heaman et al. (2002) and ages were calculated using the decay constants recommended by Jaffey et al. $\left(1971 ;{ }^{238} \mathrm{U}=1.55125 \times 10^{-10} \mathrm{yr}^{-1}\right.$ and $\left.{ }^{235} \mathrm{U}=9.8485 \times 10^{-10} \mathrm{yr}^{-1}\right)$. The ages reported have $2 \sigma$ errors.

Several samples containing subhedral to euhedral monazite grains were selected for chemical characterization and chemical age dating (Montel et al. 1996; Williams et al. 1999). Analyses were done at the Regional Electron Microprobe Laboratory at Dalhousie University, Halifax, Nova Scotia, using a JEOL 8200 electron microprobe equipped with 5 wavelength spectrometers and a 131-eV Noran Energy Dispersive Detector. The procedures used are the same as outlined in Pe-Piper and MacKay (2006) and follow the detailed protocol outlined by Jercinovic and Williams (2005). For major elemental analysis, the microprobe was operated with an acceleration voltage of 15 $\mathrm{kV}$ and probe current of $20 \mathrm{nA}$. A counting time of 20 seconds on the peaks was used with a background count time of 10 seconds. For trace element analysis, the conditions were $15 \mathrm{kV}$ accelerating voltage and $200 \mathrm{nA}$ probe current. Peak counting time was 360 seconds and background count time 180 seconds. Monazite grains were first located on polished slides using a backscattered electron (BSE) image and confirmed with the Energy Dispersive Detector prior to analyzing for chemical dating and chemistry. Age calculation used the University of Massachusetts program (Jercinovic and Williams 2005). As a check on precision and as an instrument control, monazite from Jefferson County, Colorado, which has previously dated using EMPA at between 394 to $365 \mathrm{Ma}$, was used as an interlaboratory standard (Pe-Piper and MacKay 2006). During the course of analysis, this monazite gave apparent ages of 376 to $373 \mathrm{Ma}$ and associated errors are estimated at $<5 \%$ or $\pm 15-20$ Ma for the samples in this study.

\section{ANALYTICAL RESULTS}

\section{${ }^{40} \mathrm{Ar} /{ }^{39} \mathrm{Ar}$ Age Dating}

Results for ${ }^{40} \mathrm{Ar} /{ }^{39} \mathrm{Ar}$ dating are summarized in age spectra plots in Figure 4 and data are summarized in Table 1. Samples 

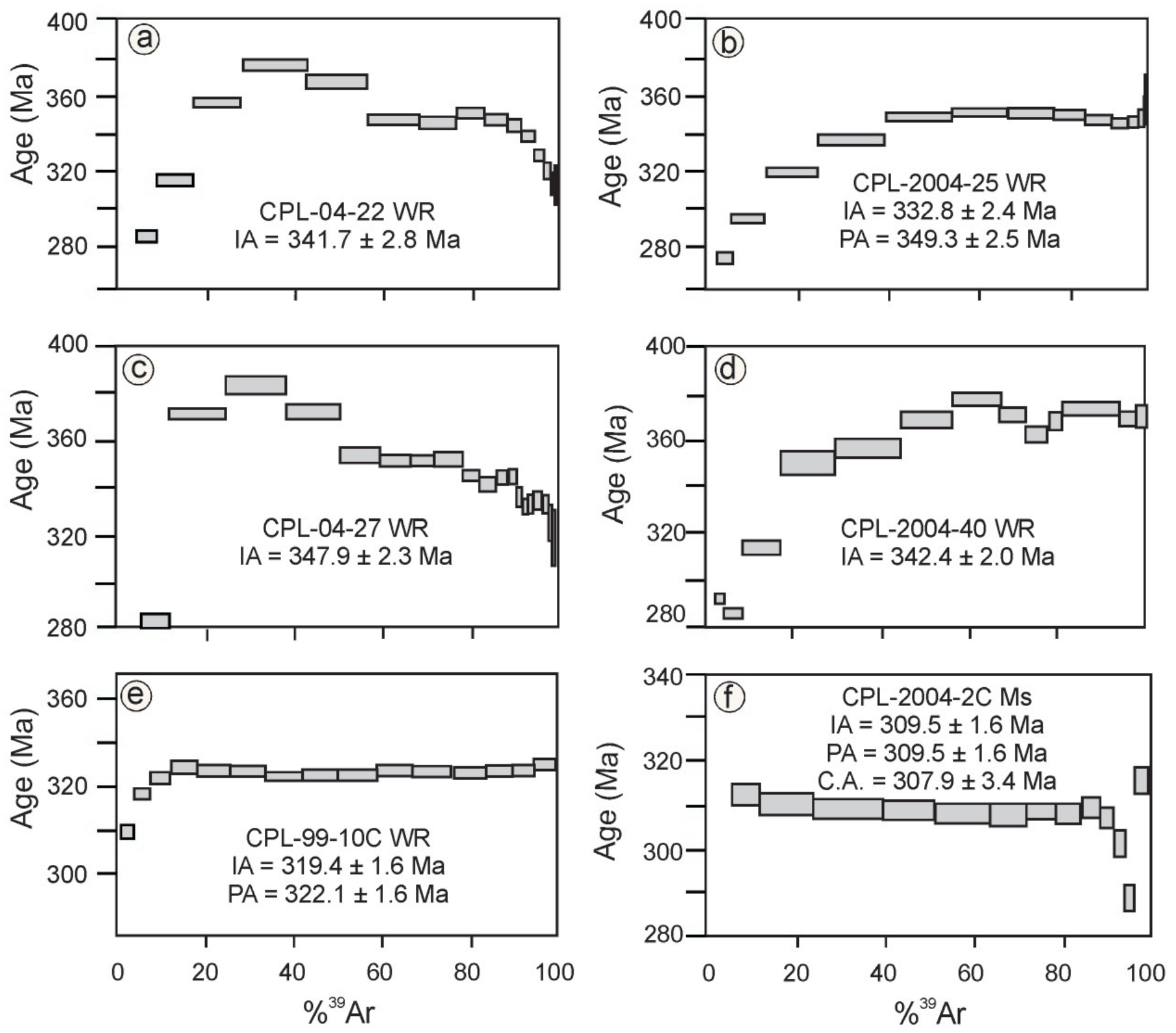

Fig. 4. ${ }^{40} \mathrm{Ar} /{ }^{39} \mathrm{Ar}$ age spectra plots for whole rocks $(\mathrm{a}, \mathrm{b}, \mathrm{c}, \mathrm{d}, \mathrm{e})$ and muscovite separate $(\mathrm{f})$ for samples from the Copper Lake area. The half heights of open rectangles indicate the $2 \sigma$ relative (between-step) uncertainties. Mean ages are given with their $2 \sigma$ uncertainties with abbreviations as follows: I.A. $=$ integrated age, P.A. $=$ plateau age, C.A. $=$ correlation age. Note that some low-temperature steps are not plotted Note that same low-temperature steps are not plotted (see Table 1 for complete data).

CPL-04-22, 04-25, and 04-27 come from the same drill hole (CPL-95-3) with CPL-04-22 and 04-25 both being black argillite containing a distinct fabric and also containing thin quartz-carbonate-pyrite veinlets. In contrast, sample CPL-0427 is a dark grey siltstone with some disseminated carbonate spots and represents an alteration zone around a mineralized vein system. Of the three age spectra, two (CPL-04-22, 27) are almost identical and are discussed first. Both spectra show increasing ages that commence near $200 \mathrm{Ma}$ and progress with increasing temperature steps to a pronounced hump around
360 to $380 \mathrm{Ma}$. This hump profile may indicate the effects of local argon recoil (McDougall and Harrison 1999). Following these humps in the spectra, a small quasi-plateau incorporating about $25-30 \%$ of the gas fraction occurs for both samples at around $350 \mathrm{Ma}$. The highest temperature steps, yielding $10-20 \%$ of gas released, give progressively younger ages down to about 320-310 Ma. The third sample, CPL-04-25, from drill hole CPL-95-3 yielded an age spectrum that shows a monotonic increase from an initial age of $<200 \mathrm{Ma}$ to a plateau at $349.3 \pm 2.5 \mathrm{Ma}$ which incorporates $51.4 \%$ of the gas. The uni- 


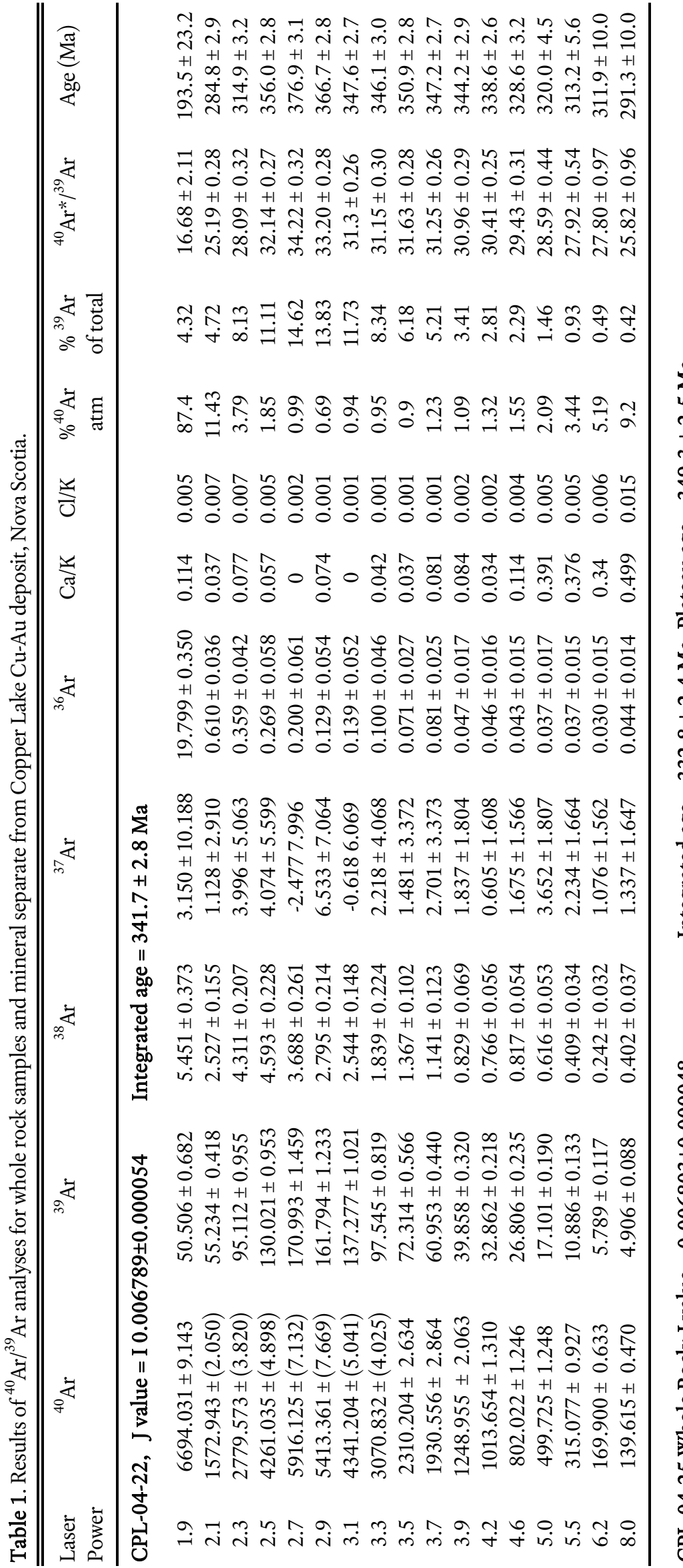

ம்

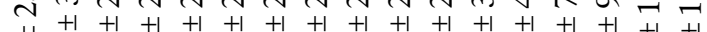

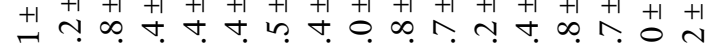

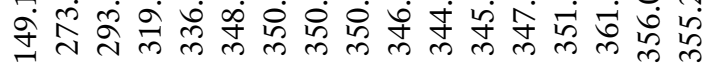

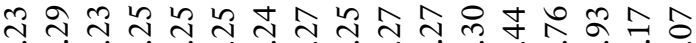

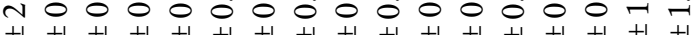

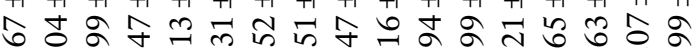
ป் வ્त

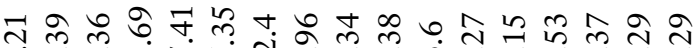
तथ

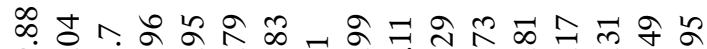
क人

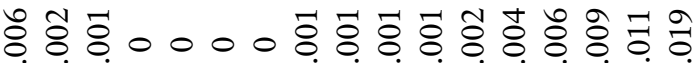

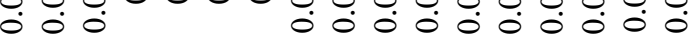

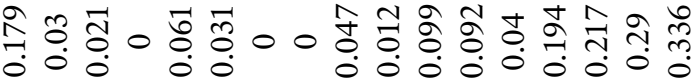

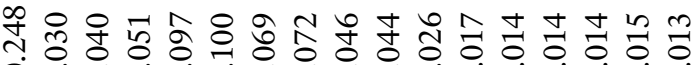

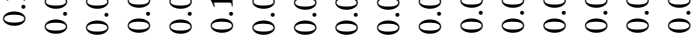

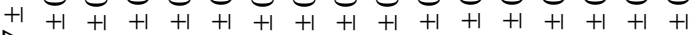
कิ

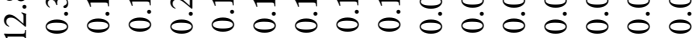

ᄋํำ

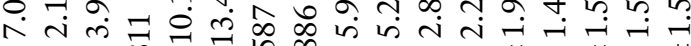

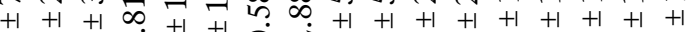
ठิ ஸ்

के

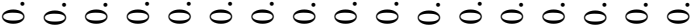

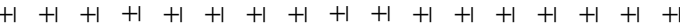
t츤 -

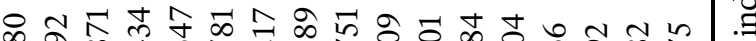
+

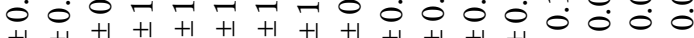
a ఫु வ்

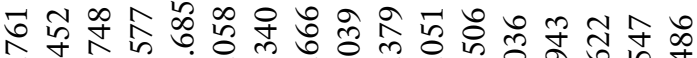

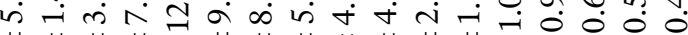

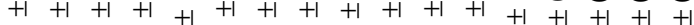
규유

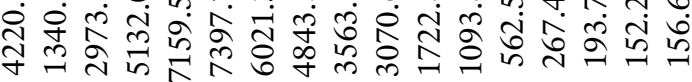

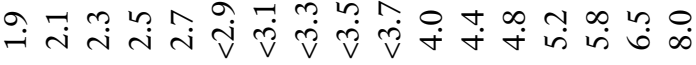




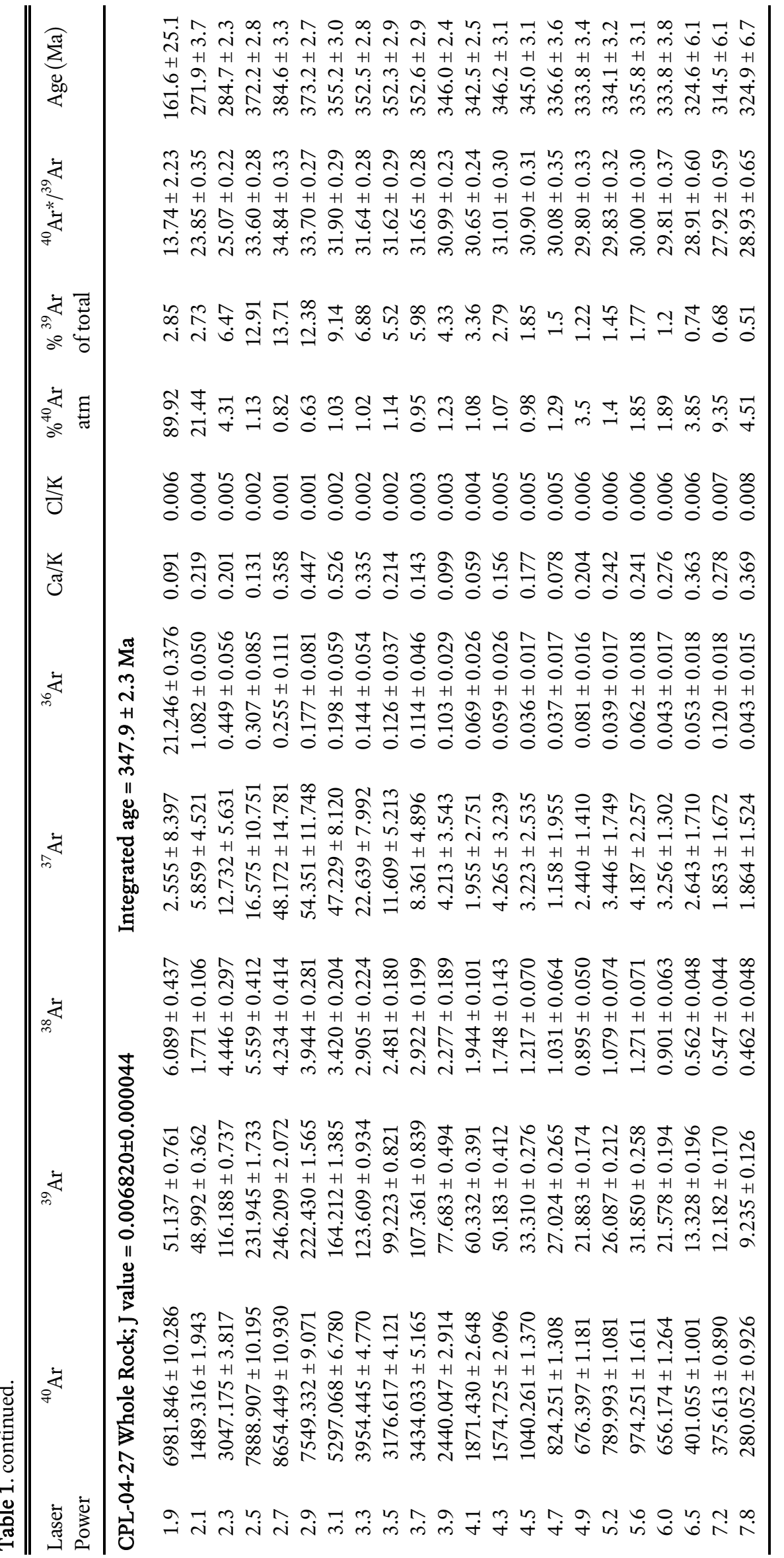

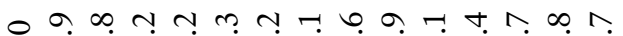
-

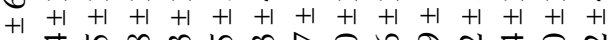

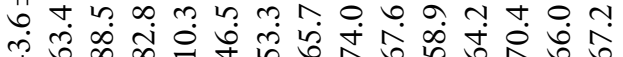
अ

ㅇำสำกี่

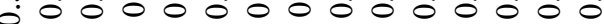
$+1+1+1+1+1+1+1+1+1+1+1+1+1$

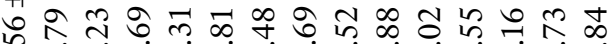
শ

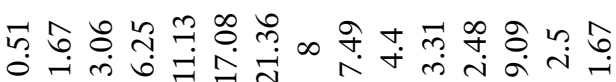

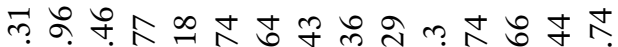
的

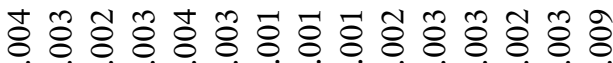

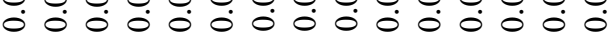

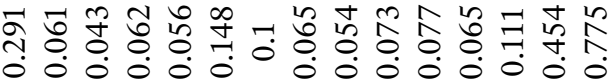

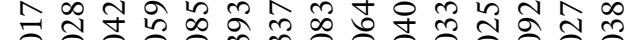
0 :

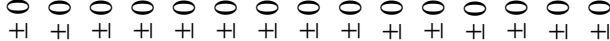
하

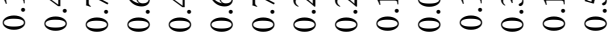

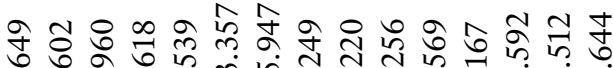

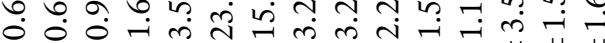

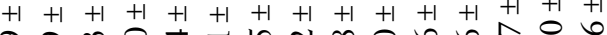
बิे

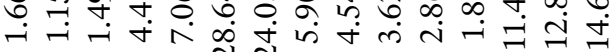

ஏำ

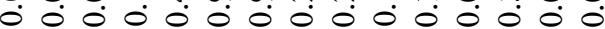
$+1+1+1+1+1+1+1+1+1+1+1+1+1+1+1$ অ

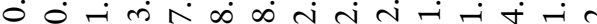

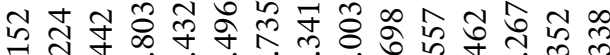
:

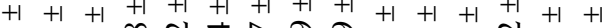

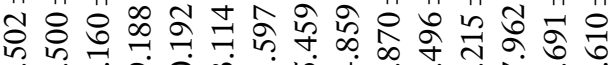

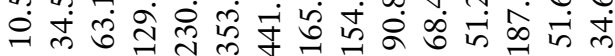

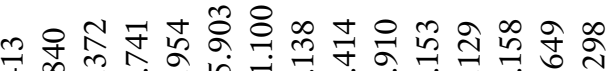

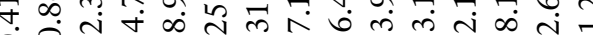
$0++1+1+1+1+1+1+1+1+1+1+1+1+1$

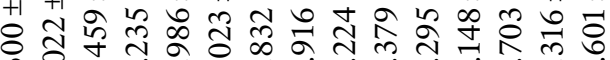

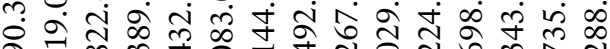

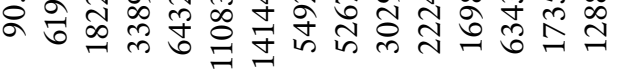

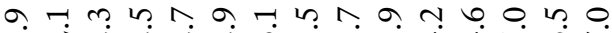

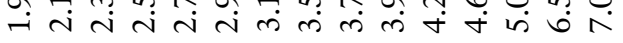




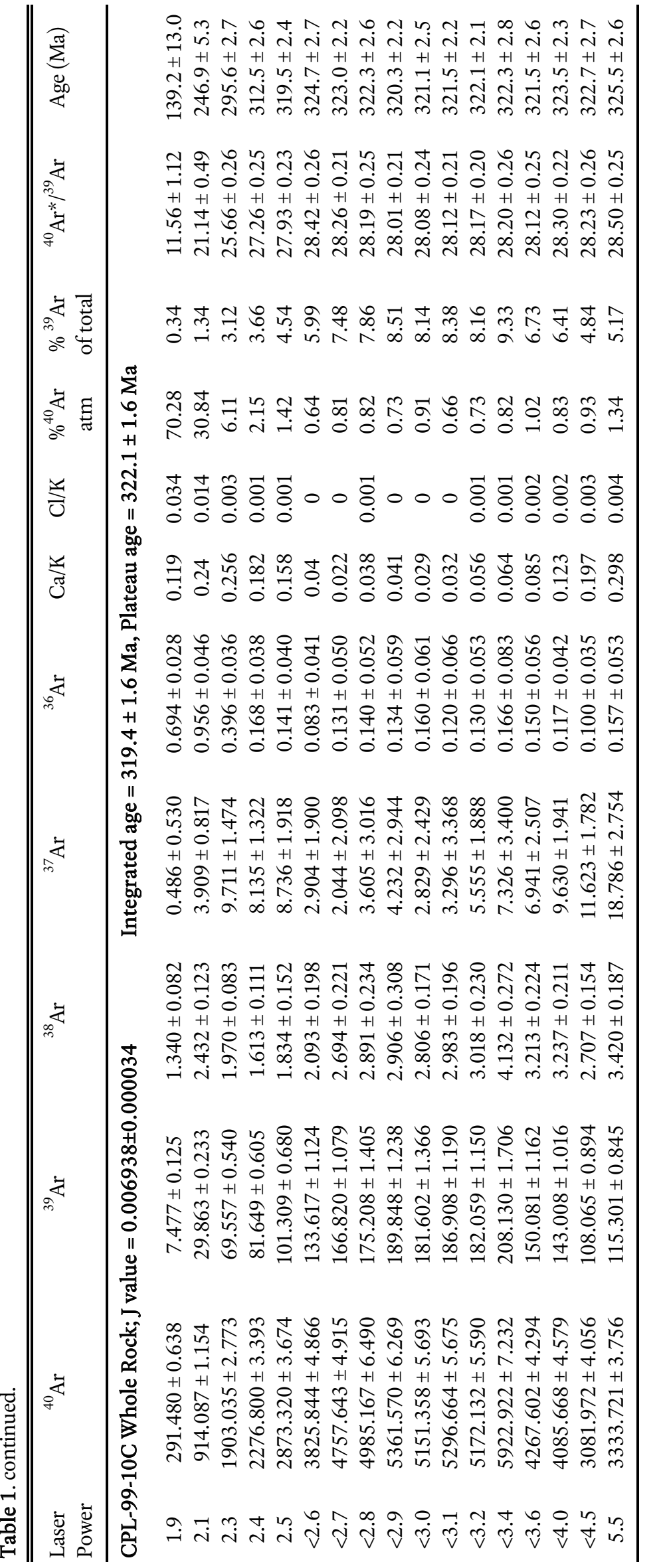

๓

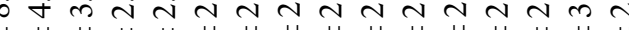

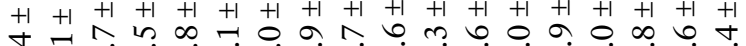

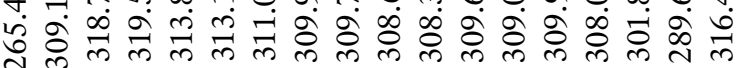

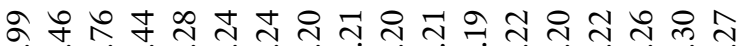

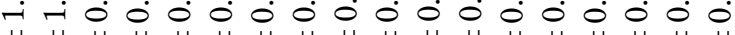

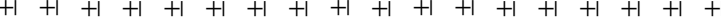

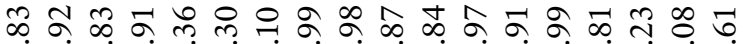
ปี่

ปิ กิ ஸे

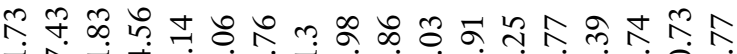

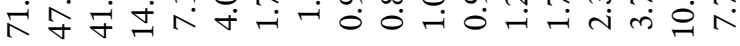

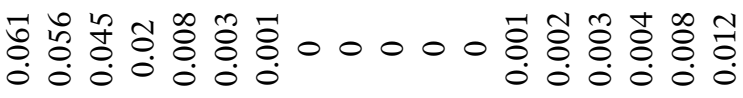

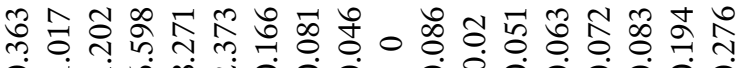

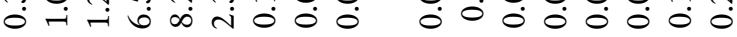

ఫ饥 రิ

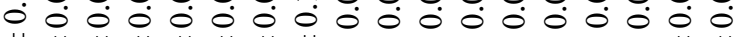

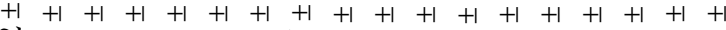
즉ㅎำ

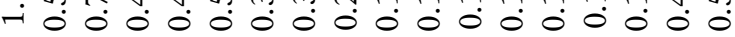

๓

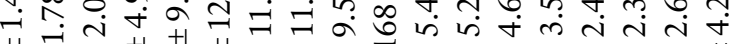

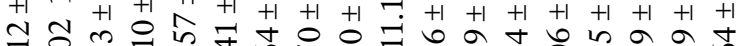
ᄏ

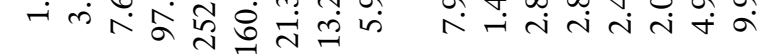

के

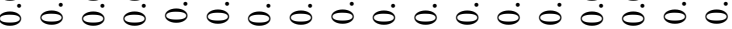

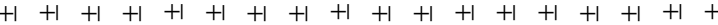
ஓ

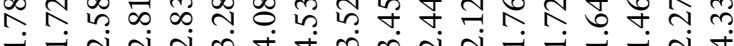

ஓ

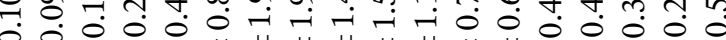

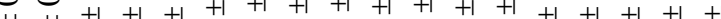
귕ㅎㅇ

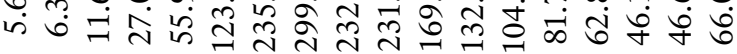

^す

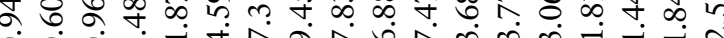

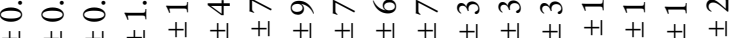

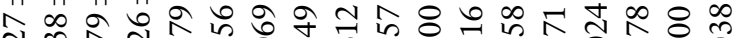
N 0 क ก 苞

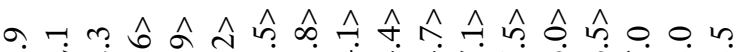

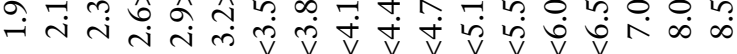

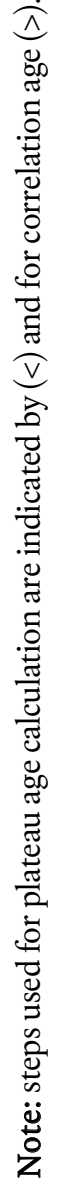


formly low $\mathrm{Ca} / \mathrm{K}$ ratios $(<0.1)$ for the whole age spectra in all of the above samples, despite their irregular profiles, indicates that gas was released dominantly from a single K-rich phase, which is interpreted to be mica.

The fourth whole-rock sample (CPL-04-40), from diamond drill hole CPL-95-2, is a fine-grained, laminated, grey-green siltstone with thin $(<5 \mathrm{~mm})$, bedding concordant, quartzcarbonate-specular hematite veins. The sample yielded an age spectrum that shows a monotonic increase in age from an initial step at $<200 \mathrm{Ma}$ to around $380-370 \mathrm{Ma}$ for the last $50 \%$ of gas released. Importantly, this sample has a uniformly low $\mathrm{Ca} / \mathrm{K}$ ratio $(\leq 0.1)$ for the whole spectrum and indicates gas release from a single, K-rich phase, probably mica.

The final two samples dated represent material from near the old workings preserved in dump piles. Sample CPL-99$10 \mathrm{C}$ is an altered siltstone with disseminated muscovite that occurs adjacent to a sulphide-bearing carbonate vein with pyrite $>$ chalcopyrite. The sample yielded a flat age spectrum, although the initial $8 \%$ of the gas liberated indicates younger ages than the plateau. A plateau age of $322.1 \pm 1.6 \mathrm{Ma}$ is defined by $81.8 \%$ of the gas released, which is similar to the integrated age of $319.4 \pm 1.6 \mathrm{Ma}$. The uniformly low $\mathrm{Ca} / \mathrm{K}$ ratios $(<0.1)$ for the gas fractions defining the plateau age indicates the gas was released from a single, K-rich phase, inferred to be the muscovite seen in the sample.

Sample CPL-2004-2C is a muscovite separate extracted from a pervasively altered siltstone adjacent to a massive carbonate-sulphide (pyrite $>$ chalcopyrite) vein. In thin section, muscovite is seen to form radiating clots of coarse muscovite intergrown with fresh, hydrothermal carbonate. This sample is considered to represent the wall-rock component of the main vein system at the deposit site. The muscovite separate yielded a flat age spectrum with a plateau age of $309.5 \pm 1.6 \mathrm{Ma}$ for $80 \%$ of the gas liberated, identical to the integrated (309.5 \pm $1.6 \mathrm{Ma})$ and correlation $(307.9 \pm 3.4 \mathrm{Ma}$ ) ages. The uniformly low $\mathrm{Ca} / \mathrm{K}$ ratio $(<0.1)$ for this sample is consistent with the gas being liberated from a single, $\mathrm{K}$-rich phase.

\section{Re-Os Dating}

Pyrite from a massive carbonate-sulphide (pyrite $>$ chalcopyrite) vein sample was separated into five individual fragments and each was analyzed for its Re and Os isotopic composition (Table 2). The pyrite has a high Re/Os ratio and the Os is highly radiogenic, the so-called "low level highly radiogenic" (LLHR; Stein et al. 2000) sulphide. The data display a well-defined linear relationship in an isochron diagram (Fig. 5) and regression of the data defines an age of $323 \pm 8$ Ma with MSWD value of 0.4 and initial ${ }^{187} \mathrm{Os} /{ }^{188} \mathrm{Os}$ value of $1.0 \pm 0.4$ ( $2 \sigma \sigma$ uncertainties).

\section{U-Pb Zircon Dating}

A sample of pervasively bleached and altered siltstone from drill core (Fig. 6a) was observed during petrographic and imaging studies to contain an anomalous amount of subhedral to euhedral, normally zoned zircon grains (Fig. 6b). The zircon was considered to possibly represent hydrothermal growth based on its abundance and habit and it was therefore separated for dating, the results of which are summarized in Table 3. Crushing of the sample yielded a multi-grain fraction $(n=40)$ of small, colorless zircon grains which have a $U$ content of 242 $\mathrm{ppm}$, Th content of $68 \mathrm{ppm}$, and Th/U ratio of 3.5 that is typi-

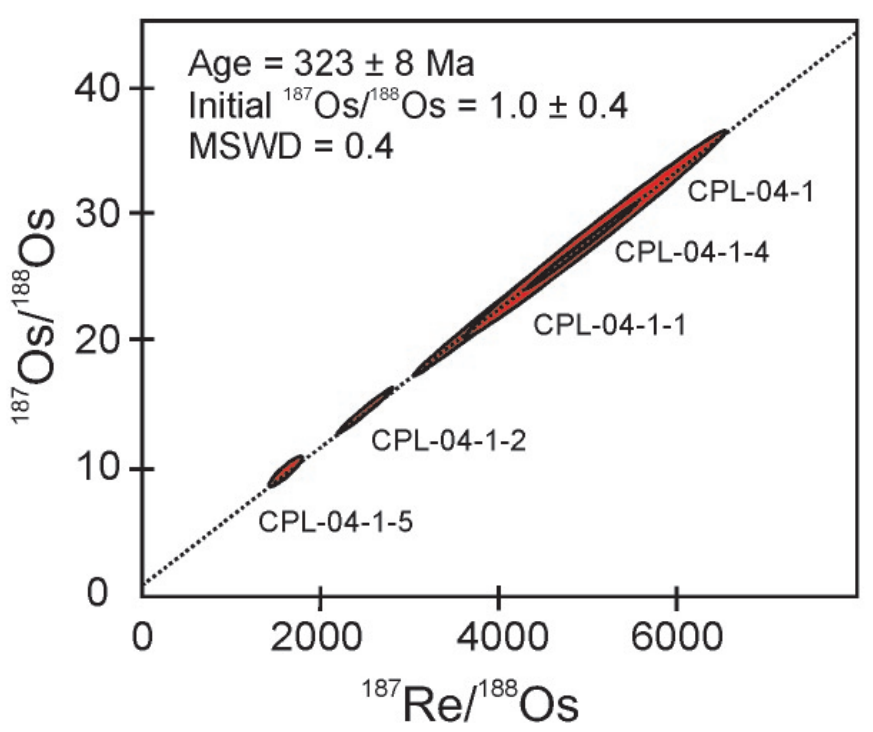

Fig. 5. Isochron diagram for the Re-Os isotopic analyses of pyrite separates for a sulphide sample from Copper Lake. The age was calculated using Isoplot/Ex (Ludwig 2003), as discussed in the text, but note that the uncertainty shown $(2 \sigma)$ does not include uncertainty in the decay constant $(\lambda)$.

Table 2. Re-Os isotope data for pyrite from Copper Lake Cu-Au deposit, Nova Scotia.

\begin{tabular}{|c|c|c|c|c|c|c|c|c|c|c|c|}
\hline Sample & Re ppb & $\pm 2 \mathrm{SE}$ & Os ppt & $\pm 2 \mathrm{SE}$ & ${ }^{192}$ Os ppt & $\pm 2 \mathrm{SE}$ & ${ }^{187} \mathrm{Re}^{/ 188} \mathrm{Os}$ & $\pm 2 \mathrm{SE}^{*}$ & ${ }^{187} \mathrm{Os}^{/ 188} \mathrm{Os}$ & $\pm 2 \mathrm{SE}^{*}$ & Rho \\
\hline CPL2004-1 & 3.743 & 0.015 & 16.8 & 4.7 & 1.5 & 0.4 & 4995 & 1252 & 28.06 & 7.03 & 0.999 \\
\hline CPL2004-1-1 & 3.983 & 0.016 & 18.0 & 3.5 & 1.8 & 0.3 & 4515 & 846 & 25.18 & 4.73 & 0.996 \\
\hline CPL2004-1-2 & 3.666 & 0.015 & 20.3 & 2.1 & 2.9 & 0.3 & 2498 & 266 & 14.50 & 1.55 & 0.994 \\
\hline CPL2004-1-4 & 2.840 & 0.012 & 13.0 & 3.8 & 1.2 & 0.3 & 4581 & 1227 & 25.75 & 6.93 & 0.996 \\
\hline CPL2004-1-5 & 3.369 & 0.014 & 23.0 & 1.8 & 4.1 & 0.3 & 1615 & 133 & 9.685 & 0.914 & 0.870 \\
\hline
\end{tabular}

* Uncertainties for these ratios are domianted by the large uncertaity in the abundance of blank ${ }^{188}$ Os.

For ${ }^{18 /} \mathrm{Os} /{ }^{188} \mathrm{Os}$, mass spectrometric uncertaities are typically $<0.5 \%$ 
cal of igneous zircon. The individual $\mathrm{Pb} / \mathrm{U}$ ages obtained (i.e., ${ }^{206} \mathrm{~Pb} /{ }^{238} \mathrm{U},{ }^{207} \mathrm{~Pb} /{ }^{235} \mathrm{U}$ ) are highly discordant, as illustrated by a standard concordia plot shown in Figure $6 \mathrm{c}$, but the calculated ${ }^{207} \mathrm{~Pb} /{ }^{206} \mathrm{~Pb}$ age is $1634 \pm 11.2 \mathrm{Ma}$.

\section{Monazite Chemistry and Th-Pb Dating}

Two samples containing monazite were selected for in situ dating using the Th-Pb chemical dating method (Montel et al. 1996; Williams et al. 1999). In this method, monazite samples with sufficient Th and of appropriate age can be dated using mineral analyses obtained from the electron microprobe and model ages calculated. As part of the procedure, the monazite grains were first characterized chemically to select material for dating. Representative chemical analyses for monazite grains along with their chrondrite-normalized rare-earth element (REE) plots and representative back scattered electron (BSE) images are provided in Table 4 and Fig. 7, respectively. The monazite grains are all Ce-rich versus the $\mathrm{Ca}$ - and Th-rich members (i.e., cheralite and brabantite; Förster 1998) of the phosphate group and have uniform chemistry. However, the BSE images indicate complex growth histories with variably sieved cores observed in some cases and euhehdral overgrowths common. The chondritic profiles and REE abundances are uniform for all the grains analyzed in the four different samples and the chemical data are typical of monazite from both igneous and metamorphic settings (e.g., Bea 1996; Förster 1998; Spear and Pyle 2002).

$\mathrm{X}$-ray maps indicate that the monazite grains are variably zoned with irregular-shaped core areas and euhedral overgrowths, as indicated from the initial observations from BSE imaging (Fig. 8). A total of twelve ages were obtained for seven grains from two samples (Table 5); two of the samples analyzed have insufficient $\mathrm{Th}$ and $\mathrm{Pb}$ concentrations to provide age determinations The data indicate ages from $387 \mathrm{Ma}$ to a low of $225 \mathrm{Ma}$ with three apparent groupings: (1) 397-370 $\mathrm{Ma}$ (4 ages), (2) 360-330 Ma (4 ages), and (3) two at 272 and $225 \mathrm{Ma}$.

\section{DISCUSSION}

\section{${ }^{40} \mathrm{Ar} /{ }^{39} \mathrm{Ar}$ Dating}

The results of ${ }^{40} \mathrm{Ar} /{ }^{39} \mathrm{Ar}$ dating indicate that several geological events are represented by the samples. The unaltered or barren whole rock samples record young ages of $\leq 200 \mathrm{Ma}$ for initial Ar release, with the higher temperature components recording ages between $350 \mathrm{Ma}$ and 380-370 Ma. The oldest plateau age of 380-370 Ma, recorded in CPL-04-40, is slightly younger than a U-Pb zircon age of $389 \mathrm{Ma}$ for felsic volcanic rocks in the Guysborough Group and similar to ${ }^{40} \mathrm{Ar} /{ }^{39} \mathrm{Ar}$ ages for whole-rock Horton Group samples from north of the Roman Valley Fault just east of the study area, which Reynolds et al. (2004) attributed to a detrital muscovite component. Based on the available information, this age would be consistent with either of the following scenarios. Firstly, inheritance via a detrital component derived from, for example, mica in granitoid rocks of the Meguma terrane to the south or metamorphic rocks to the north (e.g., Cape Porcupine Complex; White et al. 2001), which contains muscovite of the appropriate age (Reynolds et al. 2004). In regards to the detrital component, Murphy and Hamilton (2000) reported $\mathrm{U}-\mathrm{Pb}$ ages of appropriate age (i.e., 380-370 Ma) in their dataset for detrital zircons from the Devono-Carboniferous Horton Group in the St. Marys basin located south of the study area. A second explanation is that

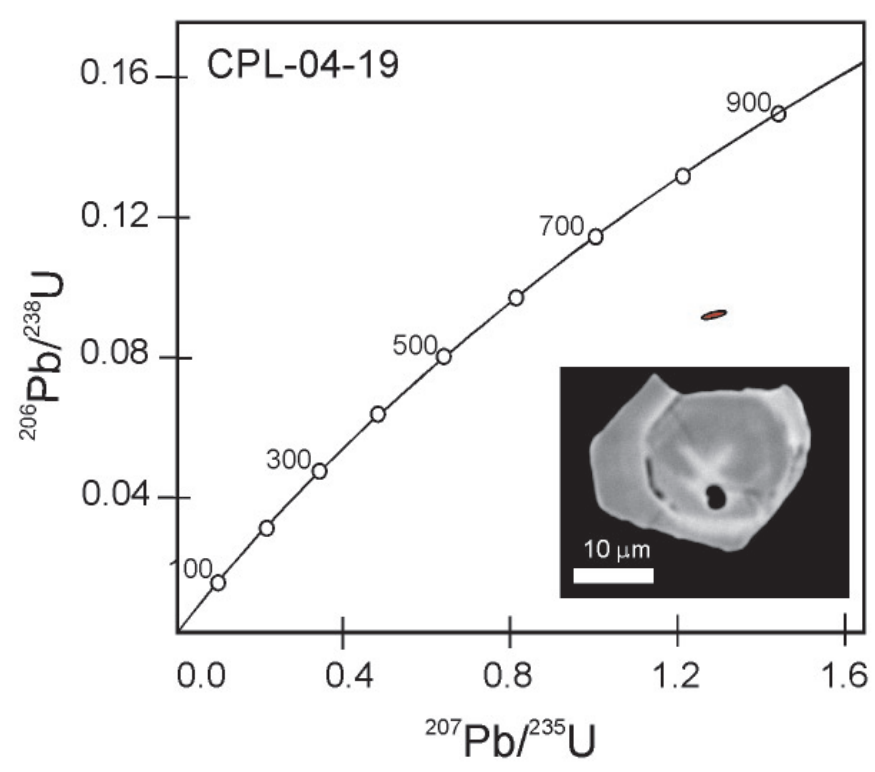

Fig. 6. Standard concordia plot for analyzed zircon fraction from sample CPL-04-19. Inset shows back scatter electron image of polished zircon grain from the sample showing typical subhedral shape that typifies the grains present.

Table 3. U-Pb TIMS Results for zircon sample CPL-04-19 from Copper Lake, Nova Scotia.

\begin{tabular}{|c|c|c|c|c|c|c|c|c|c|c|c|c|c|c|}
\hline \multirow[b]{2}{*}{ Description" } & \multirow[b]{2}{*}{$\begin{array}{c}\text { Weight } \\
\text { (mg) }\end{array}$} & \multirow[b]{2}{*}{$\begin{array}{c}\mathrm{U} \\
(\mathrm{ppm})\end{array}$} & \multirow[b]{2}{*}{$\begin{array}{c}\text { Th } \\
(\mathrm{ppm})\end{array}$} & \multirow[b]{2}{*}{$\begin{array}{c}\mathrm{Pb} \\
(\mathrm{ppm})\end{array}$} & \multirow[b]{2}{*}{$\mathrm{Th} / \mathrm{U}$} & \multirow[b]{2}{*}{$\begin{array}{c}\text { TCPb } \\
(\mathrm{pg})\end{array}$} & \multirow[b]{2}{*}{$\begin{array}{c}{ }^{206} \mathrm{~Pb} / \\
{ }^{204} \mathrm{~Pb}\end{array}$} & \multirow[b]{2}{*}{$\begin{array}{c}{ }^{206} \mathrm{~Pb} / \\
{ }^{238} \mathrm{U}\end{array}$} & \multirow[b]{2}{*}{$\begin{array}{c}{ }^{207} \mathrm{~Pb} / \\
{ }^{235} \mathrm{U}\end{array}$} & \multirow[b]{2}{*}{$\begin{array}{l}{ }^{207} \mathrm{~Pb} / \\
{ }^{206} \mathrm{~Pb}\end{array}$} & \multicolumn{2}{|c|}{ Model Ages (Ma) } & \multirow[b]{2}{*}{$\begin{array}{l}{ }^{207} \mathrm{~Pb} / \\
{ }^{206} \mathrm{~Pb}\end{array}$} & \multirow[b]{2}{*}{$\%$ Disc } \\
\hline & & & & & & & & & & & $\begin{array}{c}{ }^{206} \mathrm{~Pb} / \\
{ }^{238} \mathrm{U}\end{array}$ & $\begin{array}{l}{ }^{207} \mathrm{~Pb} / \\
{ }^{235} \mathrm{U}\end{array}$ & & \\
\hline $1 \mathrm{z}$, col tiny subhedral $(40)$ & 2 & 242 & 68 & 25.7 & 0.28 & 4 & 648 & $0.09153 \pm 18$ & $1.2687 \pm 86$ & $0.10054 \pm 61$ & $564.6 \pm 1.1$ & $831.8 \pm 3.8$ & $1634.0 \pm 11.2$ & 68.3 \\
\hline
\end{tabular}

Notes: $\mathrm{z}$ - zircon, col - colourless, number in parentheses corresponds to the total number of grains analysed. All errors in this table reported at 1 sigma. 

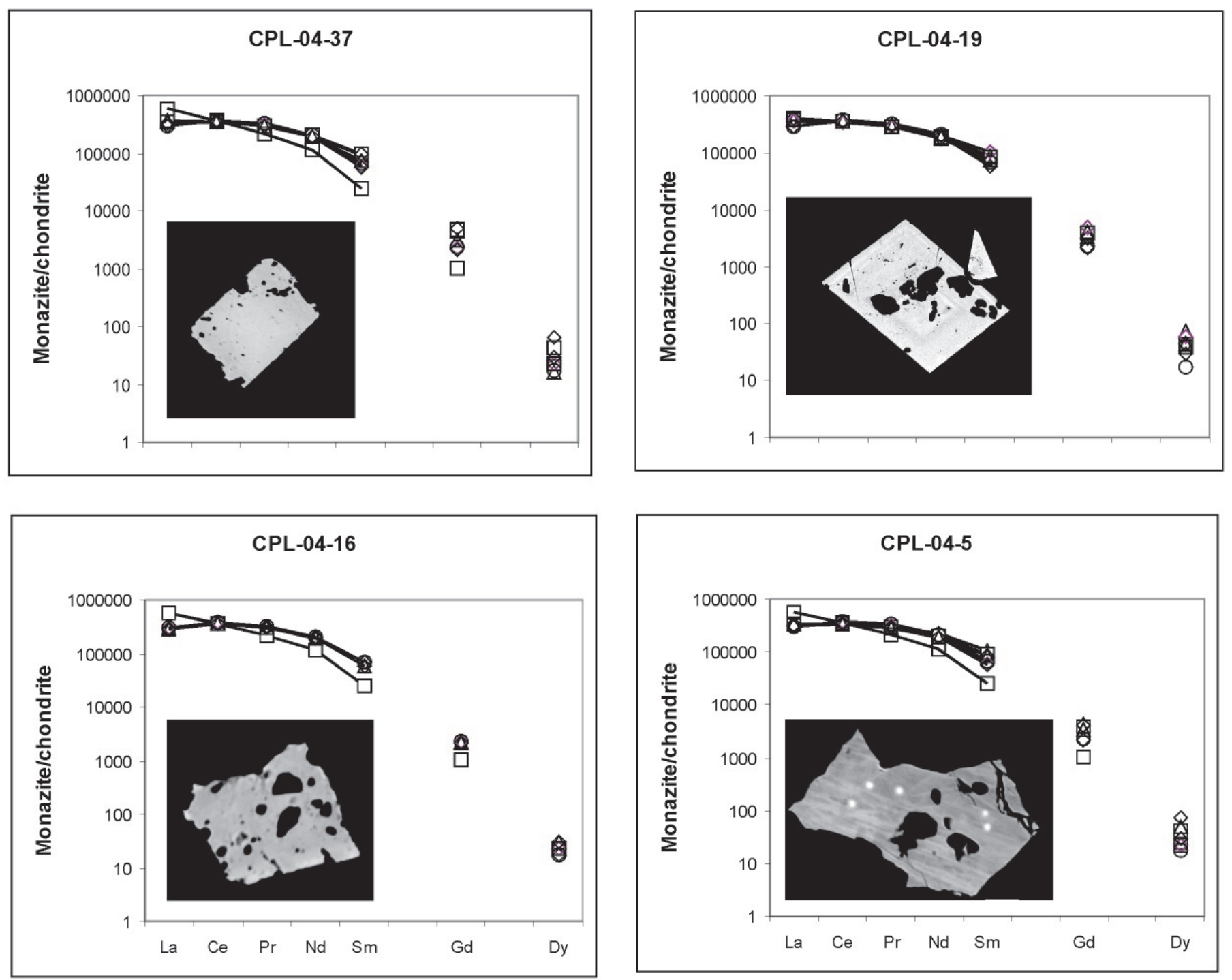

Fig. 7. Chondrite-normalized rare earth element plots for monazite grains hosted by metasedimentary rocks at Copper Lake. The inset images in each of the diagrams are back scattered electron images of analyzed monazite grains in each of the samples and the grains are about $40-60 \mu \mathrm{m}$ wide.

the ${ }^{40} \mathrm{Ar} /{ }^{39} \mathrm{Ar}$ age spectrum represents a relict depositional age for the host rocks. Given the absence of detrital muscovite in the dated sample and abundance of fine-grained mica based on petrographic study, the latter interpretation is cautiously considered to be the most likely.

Several samples record plateau ages of about $350 \mathrm{Ma}$, the most convincing being in sample CPL-04-25 where the last $51 \%$ of the gas liberated defines an age of $349 \mathrm{Ma}$. The $350 \mathrm{Ma}$ ages occur in rock samples with well-developed cleavage, therefore, this age is interpreted to indicate the time of muscovite growth during regional deformation in the area. This age is some $10 \mathrm{Ma}$ older than the timing of cleavage formation in Horton Group sedimentary rocks to the north determined by Reynolds et al. (2004). The age discrepancy may indicate that the older, more deeply buried rocks of the Guysborough Group were heated above the blocking temperature of muscovite (i.e., $>350^{\circ} \mathrm{C}$; McDougall and Harrison, 1999) before they were thrust over the Horton Group rocks during dextral compression along the CCFS (Webster et al.1998). This sequence of events would account for the difference in ages for the deformation and heating of the two sequences. On a more regional scale, this deformation is similar in age to syntectonic plutonism and continued movement along the CCFS in the Cobequid Highlands west of the study area (Pe-Piper et al. 2004; Fig. 1a).

The lack of younger plateau ages at $320 \mathrm{Ma}$ for the wholerock samples from drill core material which is altered and veined (Kontak 2006) is significant. The dated material records alteration in the form of secondary mineral growth (e.g., quartz, albite, carbonate), but evidently the temperature of the fluids attending this alteration was either not hot enough 
Table 4. Electron microprobe analyses of monazite grains (wt. \%) in metasedimentary rocks, Copper Lake, Nova Scotia.

\begin{tabular}{|c|c|c|c|c|c|c|c|c|c|c|c|c|c|c|}
\hline & $\mathrm{CaO}$ & $\mathrm{P}_{2} \mathrm{O}_{5}$ & $\mathrm{ThO}_{2}$ & $\mathrm{SiO}_{2}$ & $\mathrm{UO}_{2}$ & $\mathrm{La}_{2} \mathrm{O}_{3}$ & $\mathrm{Ce}_{2} \mathrm{O}_{3}$ & $\mathrm{Pr}_{2} \mathrm{O}_{3}$ & $\mathrm{Nd}_{2} \mathrm{O}_{3}$ & $\mathrm{Sm}_{2} \mathrm{O}_{3}$ & $\mathrm{Gd}_{2} \mathrm{O}_{3}$ & $\mathrm{Dy}_{2} \mathrm{O}_{3}$ & $\mathrm{Y}_{2} \mathrm{O}_{3}$ & Total \\
\hline CPL-04-16-2 & 0.46 & 30.45 & 0.74 & 0.07 & 0.06 & 21.55 & 35.17 & 2.98 & 8.19 & 0.58 & 0.31 & 0.09 & 0.35 & 101.00 \\
\hline CPL-04-16-4 & 0.52 & 30.46 & 2.34 & 0.15 & 0.12 & 10.95 & 35.60 & 4.25 & 14.00 & 1.32 & 0.68 & 0.11 & 0.47 & 100.97 \\
\hline CPL-04-37-1 & 0.85 & 29.59 & 0.39 & 0.11 & 0.03 & 12.98 & 34.92 & 4.13 & 14.39 & 2.12 & 1.42 & 0.13 & 0.28 & 101.35 \\
\hline CPL-04-37-4 & 0.85 & 29.49 & 0.25 & 0.05 & 0.00 & 13.57 & 34.76 & 4.19 & 13.68 & 1.76 & 0.98 & 0.06 & 0.19 & 99.83 \\
\hline CPL-04-19-1 & 0.13 & 30.05 & 0.00 & 0.02 & 0.00 & 15.13 & 34.82 & 4.16 & 13.35 & 1.80 & 1.04 & 0.28 & 0.40 & 101.17 \\
\hline CPL-04-19-2 & 0.04 & 30.42 & 0.04 & 0.00 & 0.04 & 14.64 & 35.32 & 4.15 & 13.12 & 1.93 & 1.18 & 0.17 & 0.44 & 101.50 \\
\hline CPL-04-19-3 & 0.12 & 29.80 & 0.00 & 0.00 & 0.03 & 15.10 & 35.81 & 4.20 & 13.15 & 1.78 & 1.00 & 0.17 & 0.41 & 101.56 \\
\hline CPL-04-19-4 & 0.04 & 29.97 & 0.00 & 0.00 & 0.04 & 14.42 & 35.07 & 4.11 & 13.66 & 2.10 & 1.27 & 0.17 & 0.46 & 101.32 \\
\hline CPL-04-5-2 & 0.75 & 29.88 & 1.34 & 0.12 & 0.00 & 12.59 & 34.00 & 4.24 & 14.17 & 2.11 & 1.21 & 0.15 & 0.66 & 101.24 \\
\hline CPL-04-5-3 & 0.74 & 30.03 & 3.05 & 0.19 & 0.16 & 12.21 & 32.22 & 4.00 & 13.51 & 1.98 & 1.25 & 0.28 & 0.63 & 100.24 \\
\hline CPL-04-5-4 & 0.67 & 29.72 & 2.92 & 0.16 & 0.13 & 12.37 & 33.04 & 3.95 & 13.53 & 1.95 & 1.07 & 0.19 & 0.60 & 100.30 \\
\hline
\end{tabular}
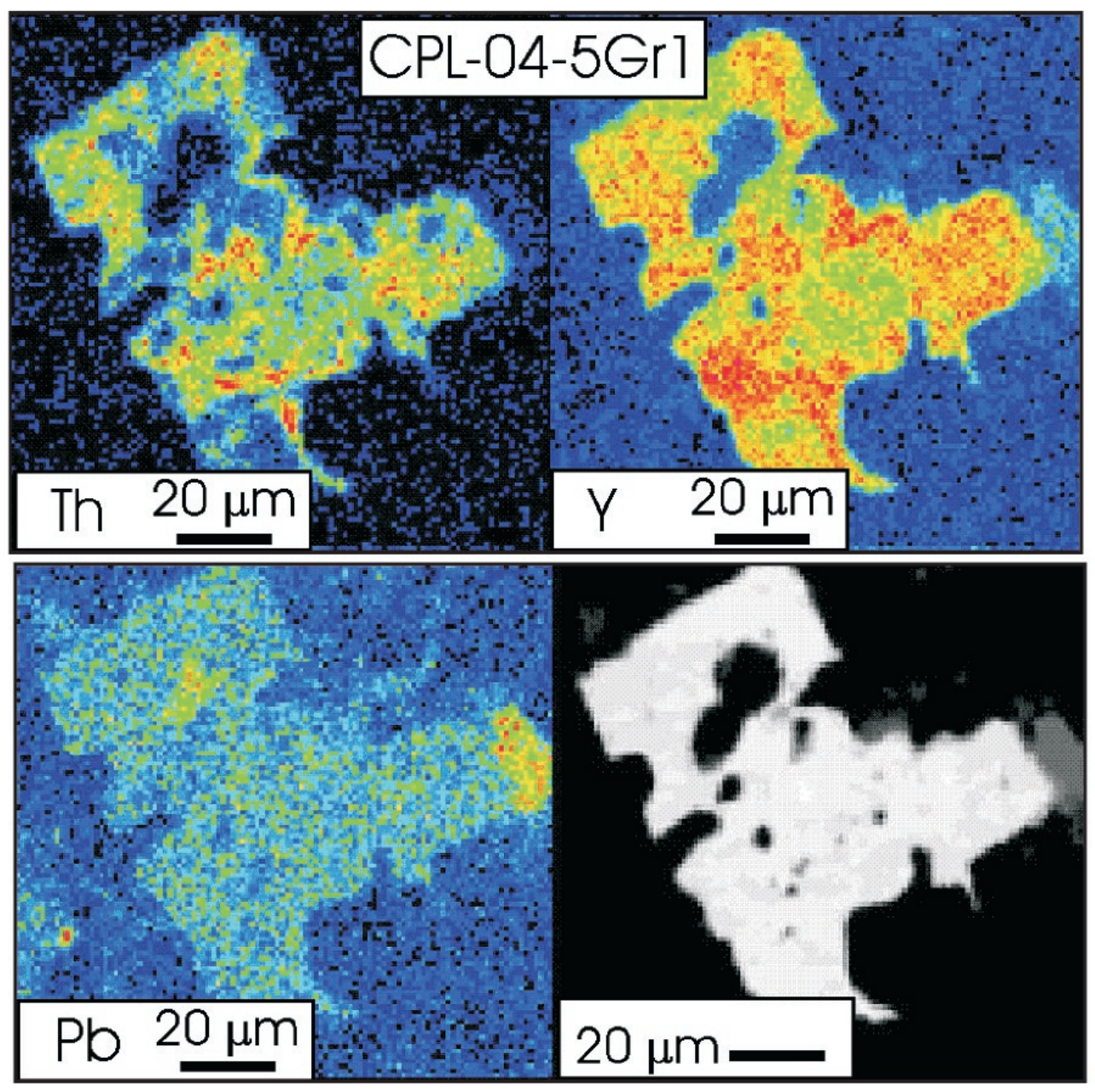

Fig. 8. Representative X-ray $\operatorname{map}(\mathrm{Th}, \mathrm{Y}, \mathrm{Pb})$ and a back scattered electron image for a grain in sample CPL-04-5 from Copper Lake that was used for chemical dating. Note the variation in the false color images that indicates variations in elemental concentrations. 
Table 5. Trace element chemistry (ppm) and calculated ages for monazite grains.

\begin{tabular}{cccccccc}
\hline \hline & Grain & $\mathrm{Y}$ & $\mathrm{Th}$ & $\mathrm{U}$ & $\mathrm{Pb}$ & $\mathrm{Pb}$ (corrected) & Age (Ma) \\
\hline CPL-04-16 & 1 & 697 & 18474 & 357 & 330 & 329 & 375 \\
& 1 & 2670 & 7019 & 20 & 91 & 86 & 272 \\
& 2 & 3438 & 3225 & 77 & 65 & 59 & 380 \\
& 3 & 344 & 24569 & 406 & 400 & 399 & 345 \\
& 3 & 106 & 18861 & 150 & 194 & 194 & 225 \\
& 4 & 0 & 15946 & 265 & 278 & 278 & 370 \\
& 4 & 0 & 22837 & 275 & 353 & 353 & 333 \\
& 5 & 1252 & 24653 & 500 & 432 & 430 & 366 \\
& 5 & 437 & 25048 & 406 & 396 & 395 & 335 \\
CPL-04-5 & 1 & 1607 & 18745 & 258 & 342 & 339 & 387 \\
& 1 & 2450 & 23038 & 484 & 403 & 399 & 362 \\
& 2 & 1610 & 38164 & 668 & 648 & 645 & 358 \\
\hline
\end{tabular}

or of sufficient duration to cause diffusive loss of argon in the samples. Given the restricted nature of the veins, their generally narrow width $(<1 \mathrm{~m})$ and high-level setting (Kontak 2006), it is apparent that the temperature away from the main ore zone was below the $250-300^{\circ} \mathrm{C}$ required to cause resetting in fine-grained, micaceous sedimentary rocks (McDougall and Harrison 1999). However, the two samples that record new growth of hydrothermal muscovite do reflect a thermal event at 320-310 Ma, which is considered to be coincident with vein-related mineralization given the restriction of the alteration to the immediate wall rock to mineralized veins. The ages for these two samples, both yielding excellent plateaus, do not overlap and due to this we note the following points. Firstly, the two samples were positioned closed to each other during irradiation and the similar values for the flux monitors (i.e., J-values, Table 1) essentially rule out analytical problems. Secondly, the muscovite grains were sufficiently coarse (i.e., 100s microns) that recoil would not be considered a potential problem (McDougall and Harrison 1999). Thirdly, given that the two samples come from the same mineralized zone, differential cooling or heating of samples is considered unlikely. Finally, the whole-rock sample is dominated by secondary hydrothermal muscovite, thus any contribution of radiogenic Ar from fine-grained metamorphic muscovite is considered not to have been significant. In addition, the excellent plateau for this sample contrasts with the irregular nature of the age spectra for whole rock samples which might be expected to be seen if outgassing of grains of different generations had occurred. Therefore, based on the two plateau ages it is concluded that the best estimate for the timing of hydrothermal activity based on ${ }^{40} \mathrm{Ar} /{ }^{39} \mathrm{Ar}$ dating is $320-310 \mathrm{Ma}$.

\section{Re-Os Dating and Initial ${ }^{187} \mathrm{Os} /{ }^{188}$ Os Ratio}

The result of Re-Os dating of vein pyrite provides a time for pyrite formation and, hence, hydrothermal activity at 323 Ma. This age overlaps within error that recorded for growth of hydrothermal muscovite in the wall rocks adjacent ore veins based on ${ }^{40} \mathrm{Ar} /{ }^{39} \mathrm{Ar}$ dating. The coincidence of these ages provides further support that the Re-Os method is a reliable and robust means of directly dating sulphide mineralization, as documented elsewhere (Arne et al. 2001; Morelli et al. 2004, 2005). Also relevant is that other workers have demonstrated the concordance of Re-Os sulphide ages with ages obtained using other chronometers (i.e, $\mathrm{Rb} / \mathrm{Sr},{ }^{40} \mathrm{Ar} /{ }^{39} \mathrm{Ar}$ ) by either dating the mineralization directly (e.g., Schneider et al. 2007) or indirectly (Selby and Creaser 2001, Masterman et al. 2004). Thus, the apparent difference of the Re-Os pyrite and ${ }^{40} \mathrm{Ar} /{ }^{39} \mathrm{Ar}$ age for sample CPL-2004-2C cannot be attributed to differences of calibration of the two chronometers. The agreement of the ReOs and ${ }^{40} \mathrm{Ar} /{ }^{39} \mathrm{Ar}$ chronometers, along with the robust nature of the Re-Os system in pyrite (Creaser 2008), provides for the first time a direct age for the mineralization along the CCFS of about $320 \mathrm{Ma}$ and allows interpretation of this mineralization in the context of its metallogenic significance.

The initial ${ }^{187} \mathrm{Os} /{ }^{188} \mathrm{Os}$ ratio, derived from regression of the Re-Os isotopic data (Fig. 5), of $1.0 \pm 0.4$ can be used to infer the nature of the reservoir for Os in the mineralizing system. This value compares, for example, to initial ${ }^{187} \mathrm{Os} /{ }^{188} \mathrm{Os}$ ratios derived from regression of Re-Os isotopic data for sulphides from a variety of other sediment-hosted mineralized settings: (1) $0.2 \pm 0.2$ for $\mathrm{Zn}-\mathrm{Pb}$ ore at the Red Dog SEDEX deposit, Alaska (Morelli et al. 2004); (2) $0.37 \pm 0.27$ for the auriferous quartz vein mineralization at Murantau, Uzbekistan (Morelli et al. 2007); (3) $1.04 \pm 0.16$ for orogenic Au mineralization, Victoria, Australia (Arne et al. 2001); and $0.83 \pm 0.15$ and 0.38 \pm 0.16 for Meguma gold veins (Morelli et al. 2005). These initial ${ }^{187} \mathrm{Os} /{ }^{188} \mathrm{Os}$ ratios indicate that a mixture of source reservoirs, from mantle to crustal, are involved in these mineralized settings. For the Copper Lake setting, the high initial ${ }^{187} \mathrm{Os} /{ }^{188} \mathrm{Os}$ ratio suggests a dominantly crustal reservoir for the Os, which is similar to that for some of the Au settings noted above and, importantly, precludes a significant mantle contribution to the Os component of this system. This conclusion is consistent with 
stable isotopic analyses $\left({ }^{18} \mathrm{O},{ }^{34} \mathrm{~S}\right)$ for the Copper Lake vein system (Kontak 2006) which indicate that the mineralizing fluids are of crustal origin.

\section{U-Pb Zircon Dating}

The single U-Pb zircon age reported indicates that the dated sample is dominantly of detrital origin, as there may be a small component of overgrowth, and thus does not preclude the presence of a hydrothermal component to the zircon in the sample. Although the data obtained are highly discordant, the ${ }^{207} \mathrm{~Pb} / 206 \mathrm{~Pb}$ age of $1634 \pm 11.2 \mathrm{Ma}$ is noteworthy as it provides some indication of the provenance for the sedimentary rocks of the Guysborough Group sedimentary rocks, which is currently lacking. Existing databases for detrital zircon exist for a large part of the Meguma (Meguma Group, White Rock and Torbrook formations) and Avalon terranes, as well as the overlapping Horton Group (summaries in Murphy and Hamilton 2000; Murphy et al. 2004). Based on these data, a likely source for detrital zircon would be the Avalon terrane, albeit locally derived in the Antigonish Highlands where an appropriate detrital zircon age population has been reported.

\section{Monazite Chemistry and Chemical Dating}

The origin of monazite in IOCG deposits is important, as enrichment in rare-earth elements is, in some cases, a chemical signature of this mineralization style (Williams et al.2005). Thus, purpose of monazite analysis was twofold, first to investigate its origin, that is detrital versus hydrothermal, and secondly to see if it could constrain the age of hydrothermal activity and rare element mobility. Twelve monazite $\mathrm{Th}$ - $\mathrm{Pb}$ ages fromr two samples indicate a large spread, from $397 \mathrm{Ma}$ to $225 \mathrm{Ma}$, which indicates either different periods of monazite growth or variable resetting of the monazite grains.

The older ages are consistent with timing of deformation in the Meguma Group to the south (e.g., Kontak et al. 1998) and suggest, therefore, a detrital origin since monazite is a common accessory phase in metasedimentary rocks. The middle age population is similar within error to whole-rock ${ }^{40} \mathrm{Ar} /{ }^{39} \mathrm{Ar}$ ages that record metamorphism in the region based on our data and earlier work (Reynolds et al. 2004), with some overlap with the age of hydrothermal activity related to mineralization. The youngest ages $(\leq 300 \mathrm{Ma})$ record yet another period of monazite growth. In summary, although not providing precise ages, the chemical dating of monazite in two samples indicates a multi-stage history for the mineral with growth both pre-dating and post-dating the time of mineralization at Copper Lake.

The rare-earth element chemistry determined for the monazite appears uniform (Fig. 7), although imaging indicates apparent zoning and chemical dating indicates a multi-stage growth history for several of the grains. Thus, in this study the chemistry cannot be used to either discriminate source regions for the detrital components (i.e., igneous vs. metamorphic) or distinguish older core regions from subsequent overgrowths.

\section{Implications for the Timing of Mineralization at Copper Lake}

One of the basic or fundamental aspects of any mineral deposit model begins with the timing of mineralization with respect to the host rock, for example syngenetic versus epigenetic modes of origin. In the case of IOCG mineralization, the relative timing of mineralization is inferred based on geological relationships supported by more detailed petrographic observations. However, determining the absolute age of mineralization, critical to formulating a model, is contingent on the presence of phases amenable to dating. In the present study, four chronometers have been applied to a well-characterized suite of samples from the Copper Lake district and two of these, Re-Os on ore-stage pyrite and ${ }^{40} \mathrm{Ar} /{ }^{39} \mathrm{Ar}$ on hydrothermal muscovite (i.e., whole rock and mineral separate), provided a reliable age for the hydrothermal activity responsible for mineralization. Thus, for the first time an absolute age has been determined for this important metallogenic domain in Nova Scotia and the age of about $320 \mathrm{Ma}$ can now be assessed in the context of the regional geological evolution of this area.

The timing of mineralization at Copper Lake overlaps the stratigraphic age, i.e., Namurian (327-315 Ma) using time scale of Okulitch (1999) for mineralized and altered host rocks at some of the IOCG-type mineralized localities in Nova Scotia, most notably Londonderry (Wright 1975; Ervine 1994) and Mt. Thom (O’Reilly 2005; Kontak 2006). It is significant, therefore, to note that similar ages, based on ${ }^{40} \mathrm{Ar} /{ }^{39} \mathrm{Ar}$ dating, as that obtained for mineralization at Copper Lake have also been reported elsewhere in southern Nova Scotia, which indicates that this thermal event is a widespread phenomenon. Firstly, Pe-Piper et al. (2004) reported ages of 330-320 Ma for hydrothermally altered lamprophyric rocks cutting older granites (i.e., $350 \mathrm{Ma}$ ) in the Cobequid Highlands (Fig. 1a). The authors suggested that this event may relate to fluids driven by a mid-crustal heat source. In addition, it was also noted that this age is coincident with Alleghanian deformation and uplift of the Cobequid Highlands and corresponds to the midCarboniferous break in Nova Scotia, a time of disconformities and unconformities in the stratigraphic record (Calder 1998). Secondly, Kontak et al. (2008; also our unpublished data) reported ${ }^{40} \mathrm{Ar} /{ }^{39} \mathrm{Ar}$ ages for several small mafic intrusions adjacent to the CCFS, some of which intrude Mabou Group (i.e., Namurian) sedimentary rocks (O’Reilly 2005). The ages span the range of 340-300 Ma, hence, in part overlapping the age of mineralization at Copper Lake. Thirdly, several ${ }^{40} \mathrm{Ar} /{ }^{39} \mathrm{Ar}$ ages have been reported throughout the Meguma terrane that document Alleghanian tectono-thermal activity and fluid movement (e.g., Reynolds et al. 1987; Kontak et al. 1995; Culshaw and Reynolds 1997; Murphy and Collins 2008). Thus, the data above indicate that coincident with the age of mineralization at Copper Lake there was widespread mafic magmatism, regional deformation, and movement of hydrothermal fluids. A model involving mobilization of fluids related to emplacement of mid-crustal mafic magma, as sug- 
gested by Pe-Piper et al. (2004) for the Londonderry area, is supported by the present study. Based on geochemical and isotopic data, both radiogenic and stable (Kontak 2006 and unpublished data), a crustal source for the mineralizing fluids at both Copper Lake and Mt. Thom is indicated.

\section{CONCLUSIONS}

This study represents the first attempt to directly date the timing of formation of $\mathrm{Cu}-\mathrm{Au}-\mathrm{Ni}$-Co mineralization associated with widespread Fe-oxide and carbonate spatially associated with the terrane-bounding Cobequid-Chedabucto Fault System of southern Nova Scotia. The mineralization has in recent years been considered as an iron oxide-copper-gold (IOCG) metallogenic district. In order to constrain the timing of the hydrothermal activity and, therefore, allow interferences regarding the origin of this metallogenic domain, a detailed geochronological study was undertaken at the past-producing Copper Lake $\mathrm{Cu}$-Au deposit, one of the more significant centres of this mineralization. The geochronological data $\left({ }^{40} \mathrm{Ar} /{ }^{39} \mathrm{Ar}\right.$, Re-Os sulphides, $\mathrm{U}-\mathrm{Pb}$ zircon, Th- $\mathrm{Pb}$ monazite chemical dating) indicate the following: (1) regional metamorphism and subsequent cooling of the Middle Devonian host rocks occurred prior to $350 \mathrm{Ma}$ based on ${ }^{40} \mathrm{Ar} /{ }^{39} \mathrm{Ar}$ whole rock ages, which is also supported by $\mathrm{Th}-\mathrm{Pb}$ chemical dating of monazite; (2) formation of the siderite-hosted $\mathrm{Cu}$-Au mineralized veins at about $320 \mathrm{Ma}$ based on ${ }^{40} \mathrm{Ar} /{ }^{39} \mathrm{Ar}$ dating of phyllic-altered wall rock adjacent to ore veins and Re-Os dating of vein pyrite; and (3) Th-Pb chemical ages of monazite, which indicates additional growth occurred during the $\mathrm{Cu}$-Au mineralizing event, hence, mobilization of rare earth elements. Dating of a fraction of euhedral zircon grains indicated a detrital rather than hydrothermal origin. The $1634 \mathrm{Ma}$ age indicates that some detritus in the Guysborough Group is of Proterozoic age.

The $320 \mathrm{Ma}$ age for mineralization is inferred to reflect structural focusing of fluids into a high-level structural setting related to the east-trending Cobequid-Chedabucto Fault System. Generation of and circulation of the fluids may relate to emplacement of mid-crustal level mafic heat source that is widespread further west in the Cobequid Highlands. However, the initial ${ }^{187} \mathrm{Os} /{ }^{188} \mathrm{Os}$ ratio determined from the analyzed sulphide indicates a crustal reservoir for Os, which is compatible with other geochemical data for the vein minerals. In addition, the timing of mineralization coincides with regional Alleghanian deformation in this part of the Appalachian orogen and thus reflects larger scale tectonothermal processes.

\section{ACKNOWLEDGEMENTS}

The data presented in this paper were acquired as the result of work undertaken when the senior author worked at the Nova Scotia Department of Natural Resources and he acknowledges the support of the NSDNR for funding this work. The chemical dating of monazite was done with the assistance of Bob McKay at the Robert McKay Electron Microprobe Facility, Dalhousie University, Halifax. The geochronological facilities at Queen's University and University of Alberta are supported in part by Natural Sciences and Engineering Research Council grants. Reviews of and comments on the paper by the journal editor, Peter Reynolds, and an anonymous reviewer are sincerely acknowledged.

\section{REFERENCES}

Arne, D.E., Bierlein, F.P., Morgan, J.W., and Stein, H.J. 2001. Re-Os dating of sulphides associated with gold mineralization in Central Victoria, Australia. Economic Geology, 96, pp. 1433-1439.

BEA, F. 1996. Residence of REE, Y, Th and U in granites and crustal protoliths; Implications for the chemistry of crustal melts. Journal of Petrology, 37, pp. 521-552.

Belperio A. 2007. Minotaur in Nova Scotia - the search for the next world-class copper-gold deposit. In Mining Matters 2007. Edited by D.R. MacDonald. Nova Scotia Department of Natural Resources, Report ME 2007-2, p. 1.

BLACK, D. 1996. Report on diamond drilling Copper Lake property; Nova Scotia Department of Natural Resources Assessment Report AR96-066, 30 p.

Calder, J.H. 1998. The Carboniferous evolution of Nova Scotia. In Lyell: The Past is the Key to the Present. Edited by D.J. Blundell and A.S. Scott, Geological Society, London, Special Publication, 143, pp. 261-302.

Cameron, H. L. 1951. Report and maps on Copper Lake mine and adjacent area, Antigonish County; Nova Scotia Department of Natural Resources, Assessment Report 11F/05C 13-B-11(02), 3 p.

Chatterjee, A.K. 1983. Metallogenic map of Nova Scotia. Nova Scotia Department of Mines and Energy, Nova Scotia, Map MCR 37, Scale 1:500 000.

Cormier, C.F.M., BARr, S.M., ANd DunNing, G.R. 1995. Geological setting and petrochemistry of early Middle Devonian volcanic and gabbroic rocks in the Guysborough area, Nova Scotia. Atlantic Geology, , pp. 153-166.

Creaser, R.A. 2008. Direct dating of sulfide mineralization by ${ }^{187} \mathrm{Re}^{187}$ Os geochronology - recent advancements, discoveries and limitations. In Unpublished Abstract Volume, Canadian Institute of Mining, Metallurgy and Petroleum Annual Conference and Exhibition, Edmonton. Paper \#3422, p. 17.

Culshaw, N., And Reynolds, P.H. 1997. Shear zones in the southwest Meguma Zone between Yarmouth and Meteghan. Canadian Journal of Earth Sciences, 34, pp. 833-.

Dalrymple, G.B, Alexander, E.C., Lanphere, M.A., AND KrAKER, G.P. 1981. Irradiation of samples for ${ }^{40} \mathrm{Ar} /{ }^{39} \mathrm{Ar}$ dating using the Geological Survey TRIGA ractor. U.S. Geological Survey, Professional Paper 1176, 55 p.

Downes, M., And Setterfield, T. 2004. IOCG potential in Nova Scotia. In Short course notes: Exploration for iron

KONTAK ET AL - Dating hydrothermal alteration and IOCG mineralization along a terrane-bounding fault zone Copyright (C) Atlantic Geology, 2008 
oxide-hosted copper-gold deposits. Edited by C. Beaudry and R. Schafer. Prospectors and Developers Association of Canada.

Dunning, G.R., Barr, S.M., Giles, P.S., McGregor, D.C., Pe-Piper, G., And Piper, D.J.W. 2002. Chronology of Devonian to early Carboniferous rifting and igneous activity in southern Magdalen Basin based on U-Pb (zircon) dating. Canadian Journal of Earth Sciences, , pp. 1219-1237.

Ervine, W. 1994. Mineral occurrences along the CobequicChedabucto Fault System. Geological Survey of Canada, Open File 2777, 503 p.

Escuder Viruete, J., Contreras, F., Stein, G., Urien, P., Joubert, M., Ullrich, T., Mortensen, J., and Perez-Estaun, A. 2006. Transpression and strain partitioning in the Caribbean Island-arc: fabric development, kinematics and Ar-Ar ages of syntectonic emplacement of the Loma de Cabrera batholith, Dominican Republic. Journal of Structural Geology, 28, pp. 1496-1519.

Förster, H.-J. 1998. The chemical composition of REE-Y-ThU-rich accessory minerals in peraluminous granites of the Erzgebirge-Fichtelgebirge region, Germany, Part I: The monazite-(Ce)-brabantite solid solution series. American Mineralogist, 83, pp. 259-272.

HaLl, C.M. 1981. The application of K-Ar and ${ }^{40} \mathrm{Ar} /{ }^{39} \mathrm{Ar}$ methods to the dating of recent volcanics and the Laschamp event. Unpublished Ph.D. thesis, University of Toronto, Toronto, Canada, $186 \mathrm{p}$.

Heaman, L.M., Erdmer, P., and Owen, J.V. 2002. U-Pb geochronologic constraints on the crustal evolution of the Long Range Inlier, Newfoundland. Canadian Journal of Earth Sciences, 39, pp. 845-865.

Jaffey A.H., Flynn, K.F., Glendenin, L.E., Bentley W.C., AND Essling, A.M. 1971. Precision measurements of halflives and specific activities of ${ }^{235} \mathrm{U}$ and ${ }^{238} \mathrm{U}$. Physics Review C4, pp. 1889-1906.

Jercinovic, M.J., AND Williams, M.L. 2005. Analytical perils (and progress) in electron microprobe trace element analysis applied to geochronology: Background acquisition, interferences, and beam irradiation effects. American Mineralogist, 90, pp. 526-546.

KePpIE, J.D. 1982. The Minas Geofracture. In Major structural zones and faults of the northern Appalachians. Edited by P. St-Julien and J. Béland. Geological Association of Canada, Special Paper 24, pp. 263-280.

KepPIE, J.D. (Compiler) 2000. Geological map of the province of Nova Scotia. Nova Scotia Department of Natural Resources and Energy, Map ME2000-1, scale 1:500 000.

KonTAK, D.J. 2006. Nature of Iron Oxide-Copper -Gold mineralization along the Cobequid-Chedabucto Fault System: An update on studies at Mt. Thom and Copper Lake. In Mineral Resources Branch Report of Activities 2005. Edited by D.R. MacDonald. Nova Scotia Department of Natural Resources, Report ME 2006-1, pp. 67-98.

Kontak, D.J., Farrar, E., McBride, S.M., and Martin, R.F. 1995. Mineral chemistry and ${ }^{40} \mathrm{Ar} /{ }^{39} \mathrm{Ar}$ dating of mus- covite from the East Kemptville leucogranite, southern Nova Scotia: Evidence for localized resetting of ${ }^{40} \mathrm{Ar} /{ }^{39} \mathrm{Ar}$ systematics in a shear zone. Canadian Mineralogist, 33, pp. 1237-1253.

KontaK, D.J., Horne, R.J., Sandeman, H., and Archibald, D.A. $1998 .{ }^{40} \mathrm{Ar} /{ }^{39} \mathrm{Ar}$ dating of whole-rock slates from auriferous veins in the Meguma Group, Nova Scotia: Evidence for post metamorphic timing of vein formation. Canadian Journal of Earth Sciences, 35, pp. 746-761.

Kontak, D.J., Horne, R.J., Creaser R.A., And Archibald, D.A. 2008. Correlation of thermo-tectonic and metallogenic events of the Avalon and Meguma terranes of Nova Scotia with the use of ${ }^{40} \mathrm{Ar} /{ }^{39} \mathrm{Ar}$ and Re-Os geochronometry. In Program with Abstracts, Atlantic Geoscience Society Meeting, Halifax, N.S., February 2008, p. 32.

Lacombe, P. 1962. Report on Copper Lake, Antigonish County; Nova Scotia Department of Natural Resources, Assessment Report 11F/0C 13-B-11(03), 32 p.

LuDWIG, K.R. 2003. Isoplot/Ex, version 3: A geochronological toolkit for Microsoft Excel: Berkley, California, Geochronology Center Berkeley, $70 \mathrm{p}$.

MacCormack, K. L. 1966. Geology of Copper Lake - South River areas, Antigonish -Guysborough Counties, Nova Scotia; Nova Scotia Department of Natural Resources, Open File Map 66-019, scale 1:15 840.

MacCoRMACK, K. L. 1967. Reconnaissance geological and geochemical investigation in the College Grant-Copper Lake-Giant Lake areas of Antigonish and Guysborough Counties, Nova Scotia; Nova Scotia Department of Natural Resources, Open File Report 558, 33 p.

Masterman, G.J., Cooke, D.R., Berry, R.F., Clark, A.H., Archibald, D.A., Mathur, R., Walshe, J.L., AND DURÁN, M. 2004: ${ }^{40} \mathrm{Ar} /{ }^{39} \mathrm{Ar}$ and Re-Os geochronology of molybdenum deposits and related copper-silver veins in the Collahuasi district, northern Chile. Economic Geology, 99, pp. 673-690.

McDougall, I., ANd Harrison, T.M. 1999. Geochronology and Thermochronology by the ${ }^{40} \mathrm{Ar} /{ }^{39} \mathrm{Ar}$ Method. $2^{\text {nd }}$ edition. Oxford University Press, New York, 269 p.

McMuluin, J. 1970. Exploration report for Great Horn Mining Syndicate, Copper Lake Claims, Antigonish County, Nova Scotia; Nova Scotia Department of Natural Resources, Assessment Report 11F/05C 13-B-11(05), 30 p.

Montel, J., Foret, S., Veschambre, M., Nicollet, C., AND Provost, A. 1996. microprobe dating of monazite; Chemical Geology, 131, pp. 37-53.

Morelli, R.M., Creaser, R.A., Selby, D., Kelley, K.D., Leach, D.L., ANd KIng, R. 2004. Re-Os Sulfide Geochronology of the Red Dog Sediment-hosted Zn-Pb-Ag Deposit, Brooks Range, Alaska. Economic Geology, 99, pp. 1569-1675.

Morelli, R.M., Creaser R.A., Selby, D., Kontak, D.J., AND Horne, R.J. 2005. Rhenium-Osmium geochronology of arsenopyrite in Meguma Group gold deposits, Meguma Terrane, Nova Scotia, Canada. Evidence for multiple 
gold-mineralizing events. Economic Geology, 100, pp. 11229-1245.

Morelli, R.M., Creaser R.A., Seltmann, R., Selby, D., Stuart, F.M., AND Graupner, T. 2007. Age and source constraints for the giant Muruntau gold deposit, Uzbekistan, from coupled Re-Os-He isotopes in arsenopyrite. Geology, 35, pp. 795-798.

Murphy J.B., Keppie, J.D., And Hynes, A.J. 1991. The geology of the Antigonish Highlands, Nova Scotia. Geological Survey of Canada, Paper 89-10, $115 \mathrm{p}$.

Murphy, J.B., ANd Collins, A.S. 2008. ${ }^{40}{ }^{39}$ white mica ages reveal Neoproterozoic/Paleozoic provenance and an Alleghanian overprint in coeval Upper Ordovician-Devonian rocks of Meguma and Avalonia. Tectonophysics, 461, pp. 265-276.

Murphy, J.B., And Hamilton, M.A. 2000. Orogenesis and basin development: U-Pb detrital zircon age constraints on evolution of the Late Paleozoic St. Mary's Basin, central mainland Nova Scotia. Journal of Geology, , pp. 53-71.

Murphy, J.B., Suarez, J.F., AND JefFries, T.E. 2004. Lithogeochemical and $\mathrm{Sm}-\mathrm{Nd}$ and $\mathrm{U}-\mathrm{Pb}$ isotope data from the Silurian-Lower Devonian Arisaig Group clastic rocks, Avalon terrane, Nova Scotia: A record of terrane accretion in the Appalachian-Caledonide orogen. Bulletin Geological Society America, 116, pp. 1183-1201.

Окицітсн, A.V. 1999. Geological Time Chart 1999. Geological Survey of Canada, Open File 3040.

O’Reilly, G.A. 2005. Mafic and felsic intrusions in Carboniferous rocks of central Nova Scotia. In Mineral Resources Branch Report of Activities 2005. Edited by D.R. MacDonald. Nova Scotia Department of Natural Resources, Report ME 2005-1, pp. 73-92.

Pe-Piper, G., ANd MacKay, R.M. 2006. of Lower Cretaceous sandstones onshore and offshore Nova Scotia from electron microprobe geochronology and chemical variation of detrital monazite. Bulletin Canadian Petroleum Geology, 54, pp. 366-379.

Pe-Piper G., Reynolds, P.H., Nearging, and Piper, D.J. 2004. Early Carboniferous deformation and mineralization in the Cobequid shear zone, Nova Scotia: an ${ }^{40} \mathrm{Ar} /{ }^{39} \mathrm{Ar}$ geochronology study. Canadian Journal of Earth Sciences, 41, pp. 1525-1436.

Reynolds, P. H., Elias, P., Muecke, G.K., And Grist, A.M. 1987. Thermal history of the southwestern Meguma Zone, Nova Scotia from ${ }^{40} \mathrm{Ar} /{ }^{39} \mathrm{Ar}$ and fission track dating study of intrusive rocks. Canadian Journal of Earth Sciences, 24, pp. 1952-1965.

Reynolds, P. H., Barr, S. M, White, C. E., and TÉniére, P. J. $2004 .{ }^{40} \mathrm{Ar} /{ }^{39} \mathrm{Ar}$ dating in the Lochaber-Mulgrave area, northern mainland Nova Scotia: implications for timing of regional metamorphism and sediment provenance in the late Devonian-Early Carboniferous Horton Group. Canadian Journal of Earth Sciences, 41, pp. 987-996.

RodDICK, J.C. 1983. High precision intercalibration of ${ }^{40} \mathrm{Ar} /$
${ }^{39} \mathrm{Ar}$ standards. Geochimica et Cosmochimica Acta, 47, pp. 887-898.

Schneider, J., Melcher, F., And Brauns, M. 2007. Concordant ages for the giant base metal deposit (DR Congo) from direct $\mathrm{Rb}-\mathrm{Sr}$ and $\mathrm{Re}-\mathrm{Os}$ dating of sulphides. Mineralium Deposita, 42, pp. 791-797.

Selby, D., And Creaser, R.A. 2001. Re-Os geochronology and systematics in molybdenum from the Endako porphyry molybdenum deposit, British Columbia, Canada. Economic Geology, 96, pp. 197-204.

Spear, F.S., AND Pyle, J.M. 2002. Apatite, monazite, and xenotime in metamorphic rocks. In Phophates: Geochemical, Geobiological and Material Importance. Edited by M. Kohn, J. Rakovan, and J.M. Hughes, Reviews in Mineralogy and Geochemistry, 48, pp. 293-335.

Steiger, R.H., ANd Jager, E. 1977. Subcommission on geochronology: Convention and use of decay constants in geo- and cosmo-chronology. Earth and Planetary Science Letters, 36, pp. 359-362.

Stein, H. J., Morgan J. W., and Scherstén, A. 2000. ReOs daring of low-level highly-radiogenic (LLHR) sulfides: the Harnäs gold deposit, southwest Sweden record continental scale tectonic events. Economic Geology, 95, pp. 1657-1671.

TÉNIÉRE, P. J. 2002. Stratigraphy, structure, and ${ }^{40} \mathrm{Ar} /{ }^{39} \mathrm{Ar}$ geochronology of the Horton Group in the Lochaber-Mulgrave area, Nova Scotia. Unpublished M.Sc. thesis, Acadia University, Wolfville, Nova Scotia, 149 p.

Webster, T. L., Murphy, J. B., and Barr, S. M. 1998. Anatomy of a terrane boundary: an integrated structural, geographic information System, and remote sensing study of the late Paleozoic Avalon-Meguma terrane boundary, mainland Nova Scotia, Canada. Canadian Journal of Earth Sciences, 35, pp. 787-801.

White, C.E., AND BARr, S.M. 1998. Preliminary geological map of Guysborough, Richmond and Antigonish Counties (parts of NTS sheets 11E/08, 11F/05, 11F/06, 11F/10, 11F/ 11, 11F/12 and 11F/15), Nova Scotia, Canada. Nova Scotia Department of Natural Resources, Minerals and Energy Branch, Open File 1998-001, scale 1:100 000.

White, C.E., ANd Barr, S.M. 1999. Geology of the Guysborough- Mulgrave-L'Ardoise area: A progress report. In Nova Scotia Department of Natural Resources, Minerals and Energy Branch, Report of Activities 1998. Edited by D.R. MacDonald and K.A. Mills. Report ME 1999-1, pp. 105-117.

White, C.E., Barr, S.M., Ketchum, J.W.F., and Ethier, M. 2001. Geology of the Cape Porcupine Complex (NTS 11F/11), Guysborough County, Nova Scotia. InMinerals and Energy Branch Report of Activities 2000. Edited by D.R. MacDonald and K.A. Mills. Nova Scotia Department of Natural Resources, Report 2001-1, pp. 83-93.

Williams, M. L., Jercinovic, M. J., AND Terry, M. P. 1999. Age mapping and chemical dating of monazite using the 
electron microprobe: Deconvoluting multistage tectonic histories. Geology, 27, pp. 1023-1026.

Williams, P. J., Barton, M. D., Johnson, D. A., Fontobé, L., De Haller, A., Mark, G., Oliver, H. H. S., and MarснIк, R. 2005. Iron oxide copper-gold deposits: geology, space-time distribution, and possible modes of origin. In Economic Geology 100th Anniversary Volume. Edited by J. Hedenquist, J. F. H. Thompson, R. J. Goldfarb and J. P. Richards. Society of Economic Geologist Inc, pp. 371-405.
WRIGHT, J.D. 1975. Iron deposits of Nova Scotia; Economic Geology Series75-1, Nova Scotia Department of Mines, $154 \mathrm{p}$.

York, D. (1969) Least squares fitting of a straight line with correlated errors. Earth and Planetary Science Letters, 5, pp. 320-324.

Editorial responsibility: Sandra M. Barr 